\title{
The Education of Alevi Religious Specialists and their Manuscripts: Ali Göktürk Dede from Şeyh Hasan Köyü, Turkey
}

\begin{abstract}
This article presents how Ali Göktürk Dede, who was a religious specialist in the Alevi tradition, was taught to use manuscripts containing texts written in Ottoman Turkish and Arabic by an older relative from his village in East Anatolia. This case study illustrates several aspects of learning and teaching in a manuscript culture that is still little researched. Using both manuscripts and oralhistory data as sources, the actors involved in education come to the fore and their different ways of using books and documents become apparent.
\end{abstract}

In a period of more than five years, I conducted numerous interviews with Ali Göktürk Dede (1932-2020), or Ali Dede for short, through which we tried to recover various aspects of his education and the practices of teaching and learning in his village, Şeyh Hasan Köyü. This article would not have come into being without his endless patience and generosity in sharing his manuscripts, knowledge, and life story with me. For this I am deeply indebted to Ali Dede. Regrettably, he passed away before I could show him the result of our work. It is to his memory that this article is dedicated. In addition, I would like to express my thanks to Aydın Gültekin, Veysel Gültekin Dede, Akar Güneş, İsmail Şahin, Turabi Şahin, Baki Ulutaş and numerous others who supported my research in many ways. ${ }^{1}$

1 Köyündeki eğitim hayatı ve kendi eğitimini çeşitli açılardan incelemeye çalıştığım Ali Göktürk Dede (1932-2020) ile beş yılın üzerinde bir süreyle bir çok görüşme gerçekleştirdim. Bilgi birikimini, el yazmalarını ve kendi hayat hikâyesini benimle paylaşırken gösterdiği sabır ve özveri, bu çalışmanın ortaya çıkmasını sağladı. Bu sebepten Ali Göktürk Dede’yeçok minettârım. Bununla birlikte, ne yazık ki çalışmamızın sonuçlarını kendisiyle, o henüz hayattayken paylaşamadım. Dolayısıyla bu makaleyi onun anısına ithaf etmek isterim. Ayrıca bu çalışmada destek veren Aydın Gültekin, Veysel Gültekin Dede, Akar Güneş, İsmail Şahin, Turabi Şahin, Baki Ulutaş ve emeği geçen herkese minnettârım.

Ә Open Access. () 2021 Janina Karolewski, published by De Gruyter. (cc) BY-NC-ND This work is licensed under the Creative Commons Attribution-NonCommercial-NoDerivatives 4.0 International License.

https://doi.org/10.1515/9783110741124-008 
Ali Göktürk Dede was born in a village called Şeyh Hasan Köyü² on the eastern bank of the Euphrates in East Anatolia. Around ten kilometres to the southwest, on the plain on the other side of the river, one can find the historical town of Malatya, which is now the district city of Battalgazi, but is still often referred to as Old Malatya (Eski Malatya) by local residents. Today's Malatya, the capital of the province of the same name, lies another ten kilometres to the south-west, and older locals like Ali Dede remember how their parents and grandparents referred to it as Aspuzu, the settlement's former name before the place-shift occurred in the nineteenth century. ${ }^{3}$

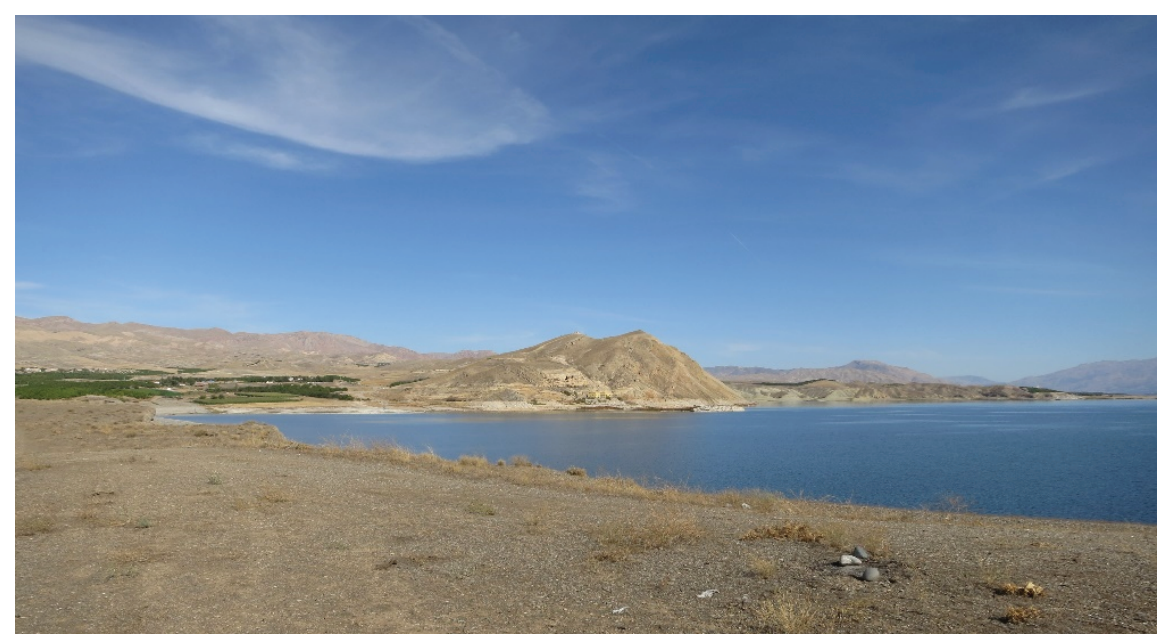

Fig. 1: View of Şeyh Hasan Köyü (on the left) from the shores of the Karakaya Dam in the northwest. Photograph by Janina Karolewski.

Şeyh Hasan Köyü belonged to the province of Elazığ ever since the Euphrates became the geographical border with the province of Malatya. When the Karakaya Dam (built from 1976 to 1987) caused the waters of the Euphrates to rise, Şeyh

2 In Ottoman documents from the sixteenth century, the village is mentioned as Şeyh Hasanlu or Şeyh Hasanlı (see Yinanç and Elibüyük 1983, 102, for example). Other modern variants of the village's name are Şı Hasan, Şeh Hasan or Şah Hasan, all of which occur in compound spelling as well. After the establishment of the Republic of Turkey in 1923, the village was renamed Tabanbükü. A couple of years ago, the village received its former name again after the villagers filed a petition to get it reinstated.

3 Sipahi 2016, 252-256. 
Hasan Köyü had to be moved and rebuilt elsewhere (see Fig. 1); the meeting places for ritual and educational purposes perished in the reservoir along with the houses and agricultural buildings. Only a few gravestones and the mausoleums located in two separate cemeteries a little outside the village were saved, being partially dismantled and then re-erected in new places. Thus, most of the village's historical setting was lost; it only survives in old photographs, ${ }^{4}$ in film footage, ${ }^{5}$ in some academic works ${ }^{6}$ and, of course, in the memories of the older villagers. The latter source of knowledge is indispensable when it comes to reconstructing how religious specialists received training in reading and writing along with their religious education.

Surviving manuscripts in the possession of several villagers are testimony to the level of training that the copyists and writers had, but they reveal very few details about how the religious specialists used them for their own purposes and for the community's educational ends. Additionally, the information gained from oral-history data partly makes up for the lack of details provided in colophons and other notes on the scribes, the owners, the users, the date and the provenance of the manuscripts, for example. It is understandable that Ali Dede and others are now unable to recall each and every detail about events that happened more than seventy years ago, but it is remarkable how far their memories can help shed some light on the use of manuscripts in Alevi communities.

\section{Education in the Alevi tradition and in Şeyh Hasan Köyü}

When Ali Dede was 10 years old, he first had to master Ottoman Turkish and some Arabic, and then got introduced to the central texts of his own religious tradition, which was apparently known under the umbrella term of Alevism from the late

\footnotetext{
4 See '1987 Öncesi' (s.a.).

5 For example, the documentary entitled 'Firat Göl Olurken' ('While the Euphrates Becomes a Lake') by Süha Arın and Hasan Özgen from 1985-1987, which is available on YouTube: <https://www.youtube.com/watch?v=F2Qr5-oPkJA> (accessed on 20 Dec. 2020).

6 The focus of those works is only on gravestones and mausoleums in the village that are said to date from the fourteenth century (see Aşan 1987 and 1998; and Serdaroğlu 1977); the vast majority of gravestones from the early twentieth century, nineteenth century and earlier were not documented. Most regrettably, the gravestones that are still accessible when the water from the Euphrates recedes are abandoned to decay now, even though they contain important details about the village's history.
} 
nineteenth century onwards. ${ }^{7}$ The holy lineages from which most Alevi religious specialists come usually claim descent from the children of Ali ibn Abi Talib and his wife Fatima, the daughter of the Prophet Muhammad, but some of them claim they are related to the Prophet's extended family. The holy lineages called ocaks are responsible for several groups of followers called talips, who usually lived in the same village as the ocak members or in surrounding villages, but sometimes lived in faraway regions. It is the ocaks' task to instruct the followers and conduct congregational rituals.

Normally, chosen males from the ocaks become religious specialists, and these days, they commonly use the title dede (lit. 'elder') after their name, just like Ali Dede, who belongs to the holy lineage named Şeyh Ahmed Dede Ocağ1 (The Ocak of Şeyh Ahmed Dede), which has its centre in Şeyh Hasan Köyü. According to local lore, Şeyh Ahmed Dede, the supposed founder of the village as well as the holy lineage and a descendant of the Prophet Muhammad, arrived at the bank of the Euphrates in the early thirteenth century. He was accompanied by his brother Şeyh Hasan Dede, after whom he named the new settlement. ${ }^{8}$ Even now, the mausoleums of Şeyh Ahmed Dede and his descendants are frequently visited by the members of his holy lineage and by affiliated followers. ${ }^{9}$

Up to the early twentieth century, most Alevi settlements were located in rural areas of Central and South-East Anatolia. It is often mentioned that Turkmen nomads - then called Kizılbaş, but now referred to as Alevis - settled in remote, mountainous regions in the aftermath of their persecution by the Ottoman State, when they sided with the Persian Safavids in the sixteenth century. The geographical location of Şeyh Hasan Köyü, however, is not in line with this general assumption about the settlement patterns of Alevi communities. The village and its religious community probably already existed in pre-Ottoman

7 See Dressler 2013. See Dressler 2008 for a short overview of the Alevi tradition.

8 See Onarlı 2001, 29, for example.

9 The inscription at the mausoleum of Şeyh Ahmed Dede, as documented by Aşan before the renewal of the building at its present site, reads as follows: 'The master of all masters, the main spiritual guide of all spiritual guides, Hoca Ahmed Yesevi, b. 1103, d. 1163' ('PİR-İ PİRÂN SERÇEŞMEY-İ MÜRŞIDÂN HOCA AHMED YESEVÎ D. 1103 Ö. 1163’, Aşan 1987, 148). The dates of his birth and death along with the suffix 'Yesevi' added to his name do not harmonise with historical research and local oral history, though. Recent findings suggest that Şeyh Ahmed Dede was a follower of the Vefai Order and was named Şeyh Ahmed-i Tavil in Ottoman records (see Karakaya-Stump 2012/2013, 294-295). Official documents attest that affiliation to the Vefaiyye and the name Şeyh Ahmed-i Tavil were still present in the seventeenth and eighteenth century (see Yllmaz 2017, 228-230 and 234-240). To the best of my knowledge, the earliest mention of the suffix 'Yesevi' occurs in a manuscript from 1820 (see MS 1) - providing that this is not a later addition. 
times, and later on, its inhabitants did not take part in any uprising against the Ottoman authorities. ${ }^{10}$

Nevertheless, it seems that Şeyh Hasan Köyü's immediate vicinity to Malatya was not particularly favourable for its inhabitants' educational requirements. Ali Dede, for example, does not recall that villagers used to receive training in one of Malatya's Qur'an schools (mekteps) or theological institutes (medreses), ${ }^{11}$ although there is a reasonable likelihood that this happened in earlier days, as we know from other Alevi communities. ${ }^{12}$ The mekteps in particular were important places for basic schooling in both literacy and Sunni Islamic education in Ottoman times. To a certain extent, the latter was also necessary when some dedes and talips took on particular religious duties, such as the office of the hocas, who had to be proficient in Arabic and were usually responsible for funeral rites, which followed Islamic practice in parts. ${ }^{13}$

The religious knowledge that is specific to the tradition had to be transmitted by the dedes, however, who are said to hold the inner teachings in oral and written form and have to maintain their secrecy. This esoteric character of the Alevi tradition was given up by many ocak members over the last few decades, but presumably it was a fixed constant previously that had a major impact on teaching and learning within the communities. Written texts, which were kept in safe custody anyway, were not perceived as ultimate sources of knowledge. Rather, the human body was allotted the task of storing knowledge by memorising texts and embodying movements or behaviour. ${ }^{14}$

It can also be argued that poor access to literacy - a historical situation, by the way, which was not remarkably different in non-Alevi villages in the Ottoman Empire $^{15}$ - fostered the dominant position of the ocaks and especially the dedes, who were crucial for the education of their followers, most of whom were

10 See Karakaya-Stump 2012/2013, 294-295. Most recent research has been covered in Weineck 2020, esp. 160-164.

11 Interview with Ali Göktürk Dede by Janina Karolewski, 23 March 2017, Malatya, Turkey.

12 See Kieser 2005, 154, for example; Shankland 2003, 25, 42, 86, 109; Andrews and Temel 2010, 304-305; and Ersal 2016b, 171.

13 See Ersal 2016a, 90, for example.

14 See Hendrich 2018, 49-51.

15 See Georgeon 1995, for instance. Georgeon mentions the exceptional case of Greeks and Armenians in the Ottoman Empire, who stand out because of their higher literacy rate in the nineteenth century (Georgeon 1995, 176). The famous Alevi poet-musician Hüseyin Karaca (1892-1989), aka Meluli Baba, went to the Armenian school in Yarpuz (today's Afşin in the province of Kahramanmaraş) from 1904 onwards. In the years before that, he had received lessons from an Arabic teacher in his village, Kötüre (Kieser 2005, 151-153). 
illiterate. As Markus Dressler has argued, the charismatic authority of the dedes, which they possessed because of their descent from the Prophet Muhammad or his extended family, was a key factor in their interpretation of religious texts. ${ }^{16}$ However, it is very likely that a considerable number of dedes were illiterate themselves, a fact presumably closely related to the historical development of their respective holy lineage and family, which led to differences in their settlement area or economic circumstances. ${ }^{17}$

Although we know about Alevi followers who achieved some skill in reading and writing, apparently they did not have access to the same texts and could not claim the same charismatic authority as the dedes. ${ }^{18}$ Nonetheless, they were important for maintaining and transmitting Alevi traditions. These cultural facilitators included the aforementioned hocas and the poet-musicians (aşıks or zakirs), who performed songs conveying central beliefs during rituals and at other social gatherings.

Presumably, the ocaks had a shared network at their command that allowed for the religious education of future dedes, either in Alevi groups or including the teaching offers made by the aforementioned mekteps, private teachers or government schools, which were introduced by the Ottoman State in the nineteenth century in order to modernise its education system. ${ }^{19}$ In some cases, military service is said to have been another way to receive training in reading and writing, and sometimes even training as an official scribe. ${ }^{20}$ Ali Dede, for example, reported that his grandfather Milla İsmail served in Yemen for seven years, where he worked in the army's chancery as a scribe. ${ }^{21}$

Parallel to Sufi orders, some Alevi villages also had meeting houses called tekke or zaviye where learning and teaching took place. These tekkes, which were often maintained by the members of a responsible household, are usually connected with a religious person who allegedly founded the place for his community. The tekke of Abdal Musa, a convent related to the Bektaşi Order, for instance, had two separate rooms for lessons at the beginning of the nineteenth century. ${ }^{22}$

16 See Dressler 2002, 17-19 and Otter-Beaujean 1997, 224.

17 See Tee 2012, 162-163, for example.

18 See Ersal 2016a, for instance.

19 See Somel 2001, for example.

20 Ali Çavuş (1863-1917) from Mezirme (now Ballıkaya) in the province of Malatya, the father of the famous Gürgür Dede from Alvar, is said to have received such training during his military service in Yemen and worked as a teacher after returning to the village (Fölster et al. 2015, 9).

21 Interview with Ali Göktürk Dede by Janina Karolewski, 3 Oct. 2013, Malatya, Turkey.

22 See Faroqhi 1995, 208. 
In Şeyh Hasan Köyü, there were several tekkes, ${ }^{23}$ which Ali Dede said had served as places for ritual gatherings and schooling and which were equipped with books. ${ }^{24}$

The use of the tekke buildings as libraries is documented in a manuscript that a certain Esma Hatun donated to the tekke of Şeyh Ahmed Dede in 1820 and which is now in Ali Dede's possession (see MS 1). ${ }^{25}$ As its colophon states, the 'dignified men' (efendis) of the village should read the book. ${ }^{26}$ (I shall discuss this manuscript in more detail shortly.) It is quite possible that 'efendi' refers to the religious specialists and other ocak members as it seems to be a title that was often used in the past for well-bred men with a high status in the social, economic and religious hierarchy of a certain group; evidence of it being used the same way in other Alevi communities also exists.

We can therefore assume that ocak members who could read consulted the books from the tekkes. Moreover, they used the books to educate the illiterate in their own village and received followers from other villages who came to Şeyh Hasan Köyü in search of spiritual guidance. ${ }^{27}$ The rituals and other ritualised gatherings in the village's tekkes, which were attended by the respective ocak members and followers alike, should not be underestimated in terms of their educational impact. The dedes read and interpreted central texts of their tradition and the aşıks or zakirs recited important songs and hymns, which the participants joined in with and memorised. ${ }^{28}$ The same applies to the learning of ritual movements, body postures, types of behaviour and even emotions. ${ }^{29}$

23 See Onarlı 1999, for instance. Among other places, Ali Dede and İsmail Şahin mentioned the tekkes of Şeyh Ahmed Dede, Teslim Abdal, Kul Mustafa, Derviş Muhammed, Derviş Ali, Kalender Abdal and Kara Şeyh (interview with Ali Göktürk Dede and İsmail Şahin by Janina Karolewski, 25 March 2014, Malatya, Turkey).

24 Interview with Ali Göktürk Dede by Janina Karolewski, 18 March 2014, Malatya, Turkey.

25 Aksüt 2013 mentions the manuscript, but dates it a century earlier, which is probably a typing error since the date appears in unmistakeable writing more than a dozen times in the book.

26 'May the efendis in Şeyh Hasan read this book and say the Fatiha prayer in favour of its owner [i.e. the donator].' ('Şeyh Ḥasan'da olan efendīler bu kitābı oḳuyub șāhịibine Fātiḥa ị̣sān edeler.') (MS 1, fol. 231 ${ }^{\mathrm{V}}$ ). Due to the irregular spelling of Ottoman Turkish in many of the sources used here, I have refrained from marking each and every instance and have used the standard spelling instead.

27 Interview with Ali Göktürk Dede by Janina Karolewski, 20 Apr. 2017, Malatya, Turkey.

28 See Karolewski 2015, 100, for example.

29 See De Rosa 2019 for this component of education in the Alevi tradition. 


\section{Ali Göktürk Dede’s education with manuscripts}

The Fountain of Hacı Ağa, a hamlet of the village

Once the lawsuit about it went on for ages

Its water is sweet, its climate is nice

I started my education in a beautiful place ${ }^{30}$

As Ali Dede (see Fig. 2) states in the above couplet of his poem 'My Village' ('Köyüm'), he began his education in a hamlet of Şeyh Hasan Köyü. This area is actually some distance outside the village, an hour's walk away on a rise above the village, and is commonly known as Üçbölük. Many old villagers refer to it by the name of 'the Fountain of Hacı Ağa', however, in reference to Seyyid el-Hacı Mustafa Ağa, aka Hacı Ağa, who lived there in the nineteenth century. ${ }^{31}$

Around 1942, it was Hacı Ağa's grandson Hüseyin Karaduman Dede (1889 or 1890/1891-1960), ${ }^{32}$ called Hüseyin Efendi (see Fig. 3), who suggested to Ali Dede's father that his son should come over to him for private lessons, which he did for about two years. The private teaching did not take place in one of the village's tekkes, however, but in Hüseyin Efendi's own house. Although some of the tekke buildings were still in sound condition at that point, it was forbidden to run tekkes from 1925 onwards. As in many cases, the former tekkes were either used for other purposes (abused, in fact) or they remained empty and gradually fell into disrepair. The villagers usually switched to family houses that were spacious enough to host a ritual gathering or a meeting for teaching purposes. This was common practice anyway in Alevi villages without a tekke.

30 'Hacı Ağa'nın pınarı köyün mezrası / Bir zaman bitmedi onun davası / Tatlıdır suyu güzel havası / Tahsile başladım bir güzel yerde'. (Unpublished typescript by Ali Göktürk Dede.) The lawsuit (dava) to which Ali Dede refers in his poem concerns the occupation of Hacı Ağa'nın Pınarı (or Üçbölük) by inhabitants from another village.

31 I was unable to locate the whereabouts of the gravestones of a number of people who are of interest here. The dates of their birth and death are unknown. For an overview of the relations between families and those between teachers and their pupils, see Diagram, p. 181.

32 According to the inscription on Hüseyin Karaduman Dede's tombstone, he lived from 1889 till 1960. In a manuscript that will be introduced in more detail in the following, his date of birth is given as $1308 \mathrm{AH}$, i.e. $1890 / 1891 \mathrm{CE}$ (see MS 2, fol. $58^{\mathrm{v}}$ ). 


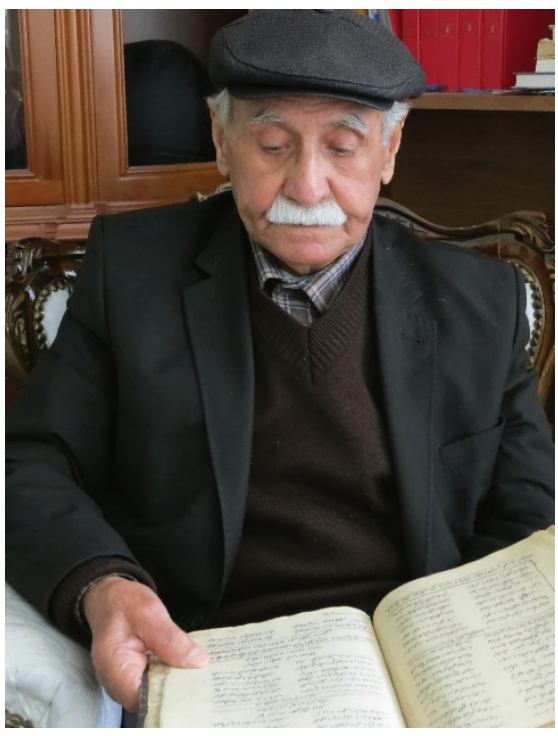

Fig. 2: Ali Göktürk Dede with MS 4, 'Divan-i Nizamoğlu', in his hands. Malatya, October 2013. Photograph by Janina Karolewski.

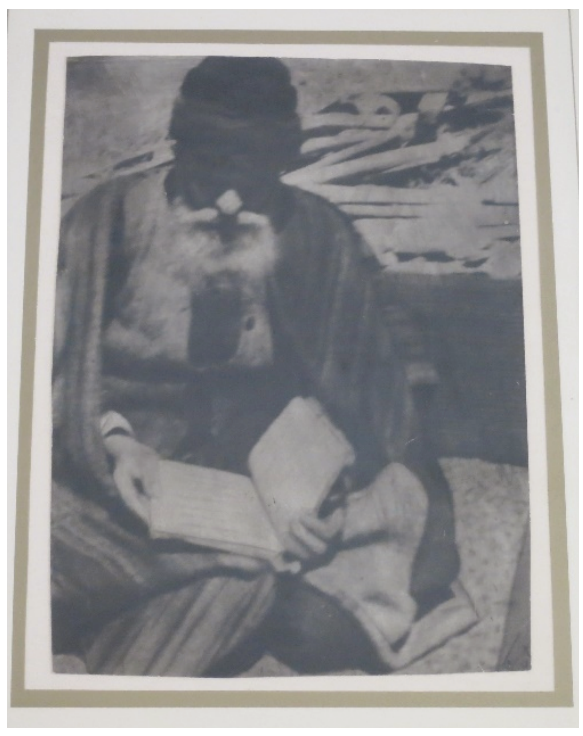

Fig. 3: Hüseyin Karaduman (undated). Picture on the wall in Veysel Gültekin Dede's house in Malatya, October 2013. Photograph by Janina Karolewski.

While the Latin script had been officially introduced more than ten years earlier, Hüseyin Efendi had good reasons to teach Ottoman Turkish and some Arabic to Ali Dede, who said he was his last student. ${ }^{33}$ Only having a command of these languages, which are both written in Arabic characters ${ }^{34}$, not Latin ones, would qualify a future dede to receive his religious education the way his ancestors did. As the manuscripts from Şeyh Hasan Köyü that are known to me show, they were often used for learning and teaching purposes - over several generations, in fact.

33 In the 1940s, Hüseyin Efendi started to lead a withdrawn life, which lasted till his death in 1960. It is commonly claimed that his spiritual retreat (çile) lasted for 23 years (see Aydın, Topalcengiz and Onarlı [s.a.], for example). According to a more detailed report, Hüseyin Efendi had already started to withdraw from worldly matters when he educated Ali Dede, but he had stayed in a small house close to his family, who provided him with food. Ten or fifteen years later, he moved to a cell-like cave in the nearby mountains. (Interview with Ali Göktürk Dede and Turabi Şahin by Janina Karolewski, 19 March 2014, Malatya, Turkey.)

34 Throughout this article, I refer to the alphabet of Ottoman Turkish as the Arabic alphabet. This also reflects how interviewees like Ali Dede made reference to the alphabet; or they simply spoke of 'the old script' ('eski yazı'). 
Hüseyin Efendi had been trained like this, just like other members of the Hacı Ağa family before him, and consequently he continued to teach the same way. Ali Dede, who was well aware of the invaluable language education that he received, expressed this once as follows:

If I had not learnt the old script [i.e. Arabic characters], I would not have acquired so much knowledge. There are a lot of rich and important books in Ottoman Turkish, and Arabic is essential, too. The dedes who know the old script are better informed than the talips, who don't have the key to the door that leads to knowledge. ${ }^{35}$

It is also notable here that Ali Dede believes that talips cannot read Arabic script, which would give them access to Ottoman Turkish writing. This could suggest that it was the prerogative of the ocak members in Şeyh Hasan Köyü to receive training in reading and writing Ottoman Turkish. Like the economic and social capital that comes with literacy in many contexts, the ability to access written texts that preserve a community's traditions must have been crucial in generating religious capital for the respective ocak, especially its dedes. ${ }^{36}$

According to Ali Dede, his father Yusuf Göktürk Dede (1899/1900-1989), aka Yusuf Çavuş, was unable to study the Arabic script sufficiently because his own father died too early for him to teach him it properly. Yusuf Çavuş was a welltrained and highly respected dede, nevertheless, but he must have felt the shortcomings in his own training, as he became a driving force in his son's education. First, he taught Ali Dede the Latin alphabet with the help of schoolbooks, ${ }^{37}$ and later when Hüseyin Efendi, asked Yusuf Çavuş to send his son to him, he agreed immediately. The two years that Ali Dede spent with Hüseyin Efendi provided him with his main training; he never attended any other school after that. ${ }^{38}$

During his education there, Ali Dede stayed in Hüseyin Efendi's home, living with his teacher's family. The two men sat on cushions on the floor when lessons were held, which took place during the day. They usually worked together first of all, then Ali Dede had to practise on his own and do some homework for the

35 'Eski yazıyı öğrenmeseydim bu kadar bilgiye sahip olmazdım. Çok zengin ve önemli Osmanlıca kitaplar var. Arapça da çok önemli. Eski yazıyı bilen dedeler taliplerden daha bilgili, onlarda bilgiye açılan kapının anahtarı yok' (Interview with Ali Göktürk Dede by Janina Karolewski, 27 Aug. 2017, Malatya, Turkey).

36 On the concept of religious capital by Pierre Bourdieu, see Rey 2018, 305-306, for example. 37 Interviews with Ali Göktürk Dede by Janina Karolewski, 8 July 2017 and 27 Aug. 2017, Malatya, Turkey.

38 When the state-run school was opened in Şeyh Hasan Köyü around 1946 or 1947, Ali Dede was too old to attend it. (Interview with Ali Göktürk Dede by Janina Karolewski, 27 Aug. 2017, Malatya, Turkey.) 
following day. All in all, he said he must have studied about twelve hours a day. His father had given him paper and a case with some pens and an ink pot, but he learnt to make ink and cut pens himself. Although there were pens with nibs made of steel, Ali Dede said that they used reed from the Euphrates or thin branches of the yılgin tree ${ }^{39}$ to make pens (kalems) themselves. Regarding inks, he explained that red ink was produced from a plant named kardeş kant $^{40}$ and black ink was made of soot taken from chimneys, for example. ${ }^{41}$

The first part of the training consisted of learning the Arabic alphabet and reading Ottoman Turkish from printed books. The two prints that Ali Dede mentioned were Nevdeste and Güldeste, ${ }^{42}$ both of which were stylistic guide books from the late nineteenth century. The latter is said to have been used in Ottoman and Armenian schools for many years, ${ }^{43}$ which could imply that someone from the village attended such a school. Ali Dede remembers that he struggled to decipher the letters in Arabic characters, not to mention the many Arabic and Persian loanwords, which he had to learn off by heart. Despite the difficult vocabulary, the two printed works have one advantage that prepared Ali Dede for the use of manuscripts: they are not typeset prints, but lithographs, the texts of which are mostly in Rlka, a very common writing style at the time, which is said to have been simpler than other styles. This is how Ali Dede became acquainted with reading handwriting, while another part of his training was dedicated to writing exercises.

The next part of his tuition was one that all the previous lessons prepared him for: Hüseyin Efendi introduced him to manuscripts containing texts that

39 The ylgin or llgin tree (tamarix parviflora DC.) belongs to the Tamaricaceae family (tamarisk) (see Ertuğ 2000, 167).

40 The only reference to the use of kardaş kanı as a dye that I have been able to find so far is in Kolaç's thesis about traditional medicine in the region of Malatya: he mentions kardaş kamı as the local name of false cleaver (galium spurium subsp. ibicinum (Boiss. \& Hausskn.) Ehrend.) and says that it was used to produce 'a kind of henna' (Kolaç 2018, 94). False cleaver belongs to the Rubiaceae family, whose species known as madder (rubia tinctorum L.; kökboya in Turkish) and yellow bedstraw (galium verum L.; yoğurt otu in Turkish) are well-known in Anatolia where they are used in the production of red dye (see Karadağ 2007, 72-75 and 107).

41 If not indicated otherwise, this and the following paragraphs of this chapter are based on interviews with Ali Göktürk Dede conducted by Janina Karolewski in Malatya, Turkey on 3 Oct. 2013, 18 March 2014, 20 Apr. 2017, 8 July 2017 and 27 Aug. 2017.

42 Nevdeste by Bedros Garabedian (1869-1937) was published in several versions in both Arabic and Armenian characters. For the Ottoman Turkish versions, see Zeki 1316 AH; or Özege 19711982, vol. 3, 1209. Güldeste by Mihran Apigian (1855-1937?) was also published in several versions; see Mihri 1303 AH; or Özege 1971-1982, vol. 2, 680.

43 Ertaş 2016, 156. 
were important for his religious education. The two manuscripts that Ali Dede remembers from the lessons (see MS 1 and 2) contain poetic works and are now in his possession. One is the epic on Müseyyeb b. Necebe (d. $685 \mathrm{cE}),{ }^{44}$ who is said to have been a companion of Imam Ali. The other comprises several stories on religious figures, such as the Prophet Muhammad, his wife Hatice (d. $619 \mathrm{CE}$ ) and the early mystic İbrahim b. Edhem (d. $777 / 778 \mathrm{cE}) .^{45}$ Ali Dede referred to the books as Müseyyib Gazi and Hatice Hatun, the latter being named after its first text, entitled 'The Story of Hatice Hatun'. ${ }^{6}$

Besides that, Ali Dede said that his teacher read and taught from the Qur'an. Since Ali Dede and another dede from the village have at least three handwritten Qur'an copies of which I am aware, it is possible that Hüseyin Efendi used a manuscript. Still, it is well-known that the Ottoman State was eager to attract Alevis and other religious groups to Sunni Islam from the late nineteenth century onwards and it began to distribute free printed Qur'ans, surah collections and catechisms as a result. ${ }^{47}$ Many Alevis did not discard these, but included them in their book collections.

It is also possible that Hüseyin Efendi made Ali Dede work on other manuscripts, but this is unclear. By looking at the manuscripts from Şeyh Hasan Köyü, which will be elaborated on in the next section, we can identify other texts that may have been taught as well. However, we should also bear in mind that Ali Dede's education did not come to an end when he left the Fountain of Hacı Ağa two years after arriving there. He usually said that he continued reading texts in Ottoman Turkish and never stopped doing so for long. His reading skills in Ottoman Turkish were excellent, so it looks as if Ali Dede had incorporated as many books as possible into his ongoing training, parts of which he must have mastered on his own or with other ocak members who shared some of their knowledge with him.

While Ali Dede admits that he initially needed a while to get used to the very individual hands of the manuscript copyists, this was only secondary to his final lessons with Hüseyin Efendi. His main task was to understand the meaning and message of the texts, which are composed in a way that only those already familiar with the tradition can follow. Hüseyin Efendi had to explain missing background

44 In Arabic, he is referred to as al-Musayyab b. Nağaba. In Turkish, the name can be written in a variety of ways, e.g. Müseyyeb, Müseyyib or Müseyib.

45 In Arabic, he is referred to as Ibrāhīm b. Adham.

46 In the following, I have employed the names of the respective manuscripts given by Ali Dede and other people since it is a convenient practice. In order to avoid any confusion, I have italicised the names of the books, but used inverted commas for the titles of texts.

47 Somel 2001, 222. 
information and interpret the texts for Ali Dede, who hardly took any notes, but tried to memorise everything. There may have been a variety of reasons for him making this decision, but presumably his teacher did not encourage him to keep on noting down what was new to him. As mentioned earlier, memorisation of knowledge seems to have been a widespread phenomenon among dedes and it was highly regarded.

Ali Dede was a passionate advocate of the educational system in which he was socialised. This became apparent during my many visits to the 'Şeyh Hasan Köyü Support Association’ ('Şeyh Hasan Köy Dayanışma Derneği’) in Malatya, where Ali Dede went to meet people connected to the village and welcome anyone interested in the Alevi tradition. When Vedat, a young man interested in the similarities between Alevism and Christianity, asked him for written sources, for example, Ali Dede answered like this:

Since you've asked for some written sources, I'll have to explain something important to you. There are two different kinds of sources: written ones and oral ones. You can destroy every written source. In fact, many of our written sources have been destroyed. But as for the oral source you keep in your mind, no-one can destroy it. ${ }^{48}$

Still, Ali Dede and others used written texts during their education in order to memorise knowledge; they copied texts and preserved them as long as possible in written form. Examples of this can be seen in most of the manuscripts that circulated in Şeyh Hasan Köyü. There are the aforementioned Müseyyib Gazi and Hatice Hatun, or Ebu Müslim and Ahmed Zemci, which I shall introduce in the next section along with other works. ${ }^{49}$ Unlike textual knowledge such as prayers and hymns, which were usually expected to be expounded or performed without reading, such stories, epics and narrations used to be read and interpreted at social gatherings. This practice is also known from other contexts such as dervish orders, and some of the texts that are supposed to have been popular in Shiite or Alevi groups were present in the Sunni milieu as well and were read in shared rooms in villages or coffee houses in cities.

48 'Sen yazılı kaynakları sorunca sana önemli bir açıklama yapmak zorundayım. İki farklı kaynak var. Yazılı kaynaklar ve sözlü kaynaklar var. Her yazılı kaynağı yok edebilirsin. Zaten çok yok edilmişler bizim yazılı kaynaklarımız. Ama sözlü kaynağı aklında tutarsın, bunu hiç kimse yok edemez.' (Ali Göktürk Dede, documented by Janina Karolewski, 8 July 2017, Malatya, Turkey.)

49 Regarding the epic on Ebu Müslim, see Albayrak 1994, 195, among others. 


\section{Ali Dede's collection and other manuscripts from Şeyh Hasan Köyü}

The collection of manuscripts that Ali Dede has compiled over the years is remarkable in many regards and requires more than the present article to do it justice academically. Nonetheless, I would like to at least mention the richness of written textual knowledge from the village and share the history of the books that I have been able to reconstruct so far. The manuscripts presented here comprise texts that are in line with what we know about the textual tradition in some Alevi communities. As Rıza Yıldırım states, the Qur'an was the most commonly owned book in the more than 300 Alevi villages in which he conducted his fieldwork..$^{50}$ The aforementioned epics, narratives and poetic works on episodes from early Islam, venerated figures or religious beliefs and practices are equally represented in collections from various Alevi communities.

As is very common in manuscript collections from Alevi communities, Ali Dede also owns a book containing the famous anti-Sunni polemic 'Kitab-i Hüsniye' or 'Risale-i Hüsniye', named after its main character, a Shiite slave girl who engages in religious debates with Sunni scholars at the court of Caliph Harun er-Reşid. ${ }^{51}$ The manuscript does not contain any notes about its scribe or when and where it was written. A marginal note by Ali Dede about the mild winter in 1954, however, gives a terminus ante quem (see MS 3). The information harmonises with my assumption that Hüsniye was copied by Hasan Gültekin (18951941/1942), ${ }^{52}$ aka Topal Hasan, a dede from Şeyh Hasan Köyü, about whom more will be said in the following. Topal Hasan was the scribe who copied another manuscript, which resembles MS 3 in regard to its layout, especially the writing style. This book, MS 4, is dated 1333 AH (1915 CE) and contains 'Divan-i Nizamoğlu', the poetry collection of the famous Sufi poet Seyyid Seyfullah Kazım b. Nizameddin, or Seyyid Nizamoğlu (d. 1601), who was affiliated with the Halveti Order.

Another item in the collection is a so-called cönk, an oblong booklet that usually contains poetry (see MS 5). As is the case with many cönks, the one in question here does not have a colophon, probably because the owners of cönks kept them for a long time and noted down texts every now and then. On fol. $60^{\mathrm{r}}$,

50 Y1ldirım 2018, 295-302.

51 See Ünal 2016, esp. 87-92.

52 The date of birth is based on a note in MS 1 , fol. $55^{\mathrm{v}}$, which states 8 Kanun I 1311 maliye (20 December $1895 \mathrm{CE}$ ). The date of his death is based on two notes in MS 4, fols $28^{\mathrm{v}}$ and $69^{\mathrm{v}}$, which state 1360 AH (1941/1942 CE). 
however, we find the abrupt mentioning of the date $1271 \mathrm{AH}(1854 / 1855 \mathrm{CE})$ under a poem's first and only couplet. The poems contained in this cönk are attributed in the very last couplet to famous aşıks of the Alevi tradition, such as Pir Sultan Abdal and Şah Hatayi. Most of them name 'Teslim Abdal' in their attribution, however, which is a pseudonym that was used by more than one poet. Among the several claims about who is behind the name of 'Teslim Abdal', there is also one that he was from Şeyh Hasan Köyü. ${ }^{53}$ And indeed, in the village they remember a dede with this name, who had lived there and was a poet. This is probably the reason why Ali Dede marked many of the poems by Teslim Abdal with the imperative 'al' (lit. 'take', probably 'copy' is meant here) or others with the note 'yazıldı' ('written down', 'copied'), presumably for a collection of poems he compiled for himself. It is therefore possible that the scribe of the cönk, who made a similar selection of texts by Teslim Abdal, came from the village or was related to it and its ocak.

The Qur'an copy in Ali Dede's collection is illuminated and has a leather cover with marbled paper pastedowns on it (see MS 6). Since the last few pages are missing, so is the colophon (if there ever was one). On the guard-leaf and pastedown at the back, however, Ali Dede added in Arabic that the scribe was a certain Şeyh Hasanlı Kılıçoğlu Mılla ${ }^{54}$ İsmail, son of Seyyid Yusuf, son of Seyyid Kul Mustafa, son of K1lıç Abdal, and the date of copying was 527 AH (1132/1133 CE). This statement seems doubtful as a whole. Kılıçoğlu Mılla İsmail is the scribe of Müseyyib Gazi, as he states in its colophon, which is dated 1235 AH (1820 CE) (see MS 1), and both scribes' hands differ substantially. Above all, though, the ostensible date lies more than a hundred years before Şeyh Hasan Köyü was supposedly founded. I propose that the copy of the Qur'an comes from the late eighteenth or nineteenth century since it resembles what is commonly known as the standard at that time in terms of its layout. ${ }^{55}$ It is possible that the scribe was from Şeyh Hasan Köyü, while the illumination and binding could have been commissioned to someone from outside the village. ${ }^{56}$ It remains to be seen why Ali

53 See Özmen 1998, 89-93.

54 'Milla' is the local version of 'molla', a title usually used for religiously trained people who teach students. I prefer to stick to the first spelling here because it is also used in the manuscripts and Alevis partly understand it as having a different meaning to 'molla' in the Sunni context.

55 See Stanley 2004, 59, among others. On common features of nineteenth-century Qur'an manuscripts, also see Witkam 2002. My thanks to Stefanie Brinkmann for pointing this article out to me.

56 This assumption is also based on the comparison to MS 7, another Qur'an copy that is in the possession of Aydın Gültekin Dede (b. c. 1974) from Şeyh Hasan Köyü. The layout again suggests that the manuscript comes from the late eighteenth or nineteenth century, but its calligraphy 
Dede made this attribution, but by adding the scribe's name, I presume he intended to mark the book as part of the village's written tradition. As we will see in the following, it was not by chance that he decided to attribute the copying to Kılıçoğlu Mılla İsmail.

Two books from Ali Dede's collection contain parts of 'Kitab-i Kerbela', a poetic work on the martyrdom of Imam Hüseyin by Darendeli Bekayi, or Darendevi Bekai (d. 1785), who, as his name indicates, came from Darende, a small town in the province of Malatya around a hundred kilometres west of Şeyh Hasan Köyü. ${ }^{57}$ The scribe of MS 8, the first book, was a certain Kangallı Topal Ahmed, who dated his copying to 1363 maliye (1947 CE). ${ }^{58}$ The affix to his name ('Kangall1') suggests that he was either from the town of Kangal in today's province of Sivas around 150 kilometres north-west of Şeyh Hasan Köyü or he came from one of the villages in the district of the same name. This is not surprising, as the area is known for its Alevi settlements. There is also a possibility that Topal Ahmed was not as lame as the epithet 'topal' suggests in Turkish, but that he had left Kangal and was living and working somewhere else that may have been very close to Şeyh Hasan Köyü. The text of the second manuscript, MS 9, was copied in $1288 \mathrm{AH}(1871 \mathrm{CE})$ by a certain es-Seyyid Muhammed Bedri, the son of muezzin Ali Efendi. The detail that his father was a muezzin gives rise to the assumption that he was not from Şeyh Hasan Köyü. Like many other Alevi villages, Şeyh Hasan Köyü does not have a mosque of its own and apparently never had one. A short invocation in the colophon, reading 'With your permission, oh spiritual master.' ('Destūr yā pīr.') (fol. 122'), may indicate that the scribe had a Sufi background.

Epic works and stories, which enjoyed popularity beyond the Shiite and Alevi milieu and were most probably read at social gatherings, are in at least four of the manuscripts from the village, two of which belong to each of the collections owned by Ali Dede and Veysel Dede, about whom we will learn more in the following. The book that Ali Dede refers to as Hatice Hatun contains several stories on the Prophet Muhammad and other important figures of early Islam. The manuscript's scribe was Hasan Efendi (b. 1839/40 $0^{59}$ ), the uncle of Ali Dede's teacher Hüseyin Efendi, who accomplished the copying in two parts in $1268 \mathrm{AH}(1852 \mathrm{CE})$

indicates that a more professional scribe was at work here. Two notes on the front guard-leaf and fol. $1^{\mathrm{r}}$ name a certain Abbas Efendi, a grandchild of Şeyh Hasanlı Ali Efendi, as its owner.

57 See Eren 2014 and Türkoğlu 2017.

58 The dating according to the Maliye or Rumi calendar after its abolition in 1926 is not a rare phenomenon.

59 His date of birth is based on the information from the colophon, in which he says he was thirteen years old in $1268 \mathrm{AH}$ (MS 2, fol. $58^{\mathrm{r}}$ ). 
and $1270 \mathrm{AH}$ (1853 CE) (see MS 2). 'Kitab-i Sultan Müseyyeb Gazi', the epic on Imam Ali's companion Müseyyeb b. Necebe (d. 685 CE), who took revenge on the murderers of Imam Hüseyin together with several other men, was copied by Kılıçoğlu Milla İsmail, son of Seyyid Yusuf, son of Kul Mustafa, in 1235 AH (1820 CE) (see MS 1). The scribe is probably the aforementioned Kilıçoğlu Milla İsmail, to whom Ali Dede attributed the copying of the Qur'an manuscript in his possession.

Veysel Gültekin Dede (b. 1932), a relative of Ali Dede's and a member of the Şeyh Ahmed Dede Ocağı, owns an undated exemplar of the poetic work commonly known as 'Destan-i Ebu Müslim' or 'Ebu Müslimname', which narrates the story of Ebu Müslim el-Horasani (d. $755 \mathrm{CE}),{ }^{60}$ a figure who played a major role in the Abbasid revolution, but was eventually killed at the command of the Abbasid caliph Al-Mansur. ${ }^{61}$ The manuscript's scribe was a certain Yusuf Efendi, son of İsmail, whom Ali Dede said was his father. As far as I could determine from the marginal notes, its terminus ante quem is 5 Kanun I 1330 maliye (18 December 1914) (see MS 10), which does not conflict with Ali Dede's claim. Among Veysel Dede's manuscripts is a book on Ebu Müslim's vice-regent Ahmed Zemci, who is said to have taken revenge for the killing of Ebu Müslim. ${ }^{62}$ The text was copied before $1180 \mathrm{AH}(1766 / 1767 \mathrm{CE})$, as a marginal note in the manuscript reveals, but we do not know anything about its scribe or provenance (see MS 11).

Last, but not least, we should turn our attention to documents and Buyruk manuscripts, which are said to have been of utmost significance in the collections of many ocak members. Usually, it is assumed that Buyruks contain the dogmatic texts of Alevi communities. ${ }^{63}$ Ali Dede did not own a Buyruk manuscript from Şeyh Hasan Köyü; he obtained access to an exemplar of one around 1997, which he made a Xerox copy of for his own needs. Judging from the copy, the original neither has a colophon nor any other informative notes in it. It is said to have been in the possession of a certain Abbas Epik (d. c. 2010) who came from Kumlutarla (old name: Ataf Köyü), ${ }^{64}$ a village that lies some 35 kilometres to the north-east of Şeyh Hasan Köyü on the banks of the Euphrates. Kumlutarla is the centre of the Şıh Bahşiş Ocağı and had a tekke of its own in the past. ${ }^{65}$ Although Ali Dede

60 In Arabic, he is referred to as Abū Muslim al-Hurūāānī.

61 See Babayan 2002, 121-160, and Mélikoff 1962.

62 On works narrating the story of Ahmed Zemci, see Babayan 2002, 153, endnote 37. Also see the text 'Kitab-i Ahmed ez-Zemci' in 06 Mil Yz A 6061, Milli Kütüphane, Ankara, Turkey.

63 For more on Buyruks, see Kaplan 2010, Otter-Beaujean 1997 and Karolewski in the present volume (see below, section 'Modifying Tradition').

64 Interview with Ali Göktürk Dede by Janina Karolewski, 3 Oct. 2013, Malatya, Turkey.

65 See Onarlı 2000, 119-122. 
mentioned several times that there had been Buyruk manuscripts in Şeyh Hasan Köyü, I have not been able to discover their whereabouts yet.

Regarding documents in Alevi family archives, the most common ones are genealogies called şecere or silsilename, which often confirm the family's descent from the Prophet Muhammad, and certificates called icazetname, which certify the holder's affiliation with a certain Sufi order. ${ }^{66}$ Frequently, these genealogies and certificates are found in one and the same document. It seems that many icazetname documents lost their original function over the course of time and began to serve as certificates documenting the religious status of their holders instead, namely their descent from the Prophet Muhammad and one of the Alevi holy lineages. ${ }^{67}$

The oldest document from Şeyh Hasan Köyü is said to be a certificate dated 1 Muharrem 829 AH (12 November 1425), which presents the line of ancestry of its holder from a certain Şeyh Ahmed el-Cemi (allegedly Şeyh Ahmed Dede) and confirms the latter's affiliation with the Vefai Order. ${ }^{68}$ Ali Dede remembers that such documents, which were normally scrolls with an impressive layout, were exhibited and read to the followers in Şeyh Hasan Köyü on occasions such as the collective mourning that took place in the month of Muharrem. ${ }^{69}$

These genealogies were an important means of backing up the ocak's claim to descend from the family of the Prophet Muhammad through Şeyh Ahmed Dede, which granted its members several privileges, including the right to use the honorific title of 'seyyid', as we have already seen in some of the names mentioned above. The only document of this kind that Ali Dede has in his collection appears to be a certificate from Kerbela, which is dated $1135 \mathrm{AH}$ (1722/1723 CE) and relates several individuals to the Prophet Muhammad and the Vefaiyye via Şeyh Ahmed Dede (see MS 12). I am convinced that someone manipulated the document in order to make it suitable for their own ends, but I cannot go into much detail about it here as that would go beyond the scope of this article. ${ }^{70}$ It is

\footnotetext{
66 See Karakaya-Stump 2010, 274-275.

67 Karakaya-Stump 2012/2013, 286.

68 Aşan 2005. Also see 'Tâcû'l-Ârifîn' (s.a.).

69 Interview with Ali Göktürk Dede by Janina Karolewski, 29 March 2017, Malatya, Turkey. Akar Güneş confirmed that this practice is said to have existed in the village and is still being continued by some dedes today. (Telephone interview with Akar Güneş, Schweinfurt, Germany, by Janina Karolewski, 20 Oct. 2018.)

70 Apart from several passages where someone altered words or erased them, its content and form do not correspond to similar documents I have seen. While the document gives the genealogy of a certain Zeyd ibn eş-Şeyh, other names are placed at the top and bottom of the scroll. I cannot say how they relate to its text yet. They include Kul Mustafa, Seyyid Kılıç, Derviş Teslim,
} 
interesting, however, that there are two names among the seyyids mentioned in this document that were frequently used among Ali Dede's ancestors: Kul Mustafa and Kılıç. The latter became particularly famous since the family as a whole used to be called Kılıçoğulları, or the Sons of Kılıç (their surname is now Göktürk). ${ }^{71}$ As oral lore reports, the Kılıçoğulları are said to be the descendants of Şeyh Ahmed Dede's grandchild Şeyh Cüneyd, while the other dede families in the village are supposed to be the progeny of his grandchildren Şeyh Şemseddin, Şeyh Davud and Seyyid Ahmed (see Diagram, p.181, regarding the family relations covered here and in the following). ${ }^{72}$ These differences in lineage divided the members of the Şeyh Ahmed Dede Ocağ 1 and created subgroups within the village, which kept separate records of their lines of descent. ${ }^{73}$

Another document from Kerbela dated Receb 1274 AH (February/March 1858) is only available in the form of a rough transcription that Ali Dede made with a typewriter. The şecere attests the status of seyyid to a certain Seyyid Kul Mustafa, son of Seyyid İsmail, son of Seyyid Yusuf, son of Seyyid Kılıç Abdal - once again a member of the Kılıçoğulları and perhaps the son of Kılıçoğlu Mılla İsmail, the scribe who copied Müseyyib Gazi (see MS 1). Just like the previous document, the transcript poses several questions about its authenticity, which I cannot answer now, as they are irrelevant for the point I wish to make here. ${ }^{74}$ What is central here is that the Kılıçoğulları, just like other dede families from Şeyh Hasan Köyü, ${ }^{75}$ felt the need to possess written evidence of their lineage in the form of certificates.

Besides this, there are other written traces as well that show what emphasis was placed on family history, even if they are just abbreviated versions of the complete lineage mentioning only the most significant ancestors. In the margins on fols $2^{r}-3^{r}$ of MS 9, for instance, Ali Dede seems to have compiled passages from the document on which the aforementioned transcript is based. In short, he notes

Derviş Hüseyin, Seyyid Koca, Seyyid Ali, Seyyid Ahmed, Seyyid Kanber and Seyyid Yusuf. Given the fact that most of these names were common in dede families in the village, I am inclined to relate them to Şeyh Hasan Köyü (compare them with the names mentioned in Yılmaz 2016, for example).

71 See Aksüt 2013.

72 Interviews with Ali Göktürk Dede by Janina Karolewski, 3 and 5 March 2014, Malatya, Turkey.

73 One subgroup traces back their lineage to Şeyh Şemseddin through the famous, but historically elusive Teslim Abdal and claims to have become an ocak on its own, namely the Teslim Abdal Ocağı. See Akın and Yılmaz 2017.

74 One of the main questions concerns the mismatch between the first lines, which trace Kul Mustafa, the supposed holder of the document, back to Şeyh Ahmed Dede via Şeyh Cüneyd and the following detailed passage, in which the lineage goes via Şeyh Şemseddin to Şeyh Ahmed Dede.

75 See Akın and Yilmaz 2017, for example. 
that Kul Mustafa is descended from Kılıç Abdal and Şeyh Ahmed Dede, while the latter, in turn, is descended from Abbas, the son of Imam Ali. It comes as no surprise, then, that Ali Dede attributed the Qur'an copy to a member of the Kılıçoğulları, naming the scribe's ancestors as Kul Mustafa and Kılıç Abdal in the note that he added later. ${ }^{76}$

\section{Education in family networks}

In order to understand how Ali Dede and other dedes in Şeyh Hasan Köyü used manuscripts for teaching and learning, I searched for evidence in the books I was able to access. I quickly realised that the practice of teaching with manuscripts strongly depended on oral tuition, as I could hardly find any annotations, corrections or other kinds of glosses that could be cited as examples of educational work with them. Fortunately, the users of some of the books occasionally left notes that helped me gain insights into the educational network of certain families (see Diagram, p. 181). Unfortunately, I have not been able to reconstruct this tightly woven network in its entirety, but my findings indicate how teaching might have been organised on a wider scale.

The earliest dated evidence of teaching found in the manuscripts so far lies between the lines of the first colophon from Hatice Hatun (MS 2, fol. $58^{\mathrm{r}}$ ), in which the scribe, Hasan Efendi (b. 1839/1840), says he was thirteen years old on 8 Şaban $1268 \mathrm{AH}$ (28 May 1852) and the pupil of a certain Milla Yusuf. The title 'milla', or 'molla', does not necessarily indicate he was a teacher, but Ali Dede remembers that several dedes were called 'milla' because they were actively involved in educating ocak members and followers. Interestingly, he elaborated that his grandfather and great-grandfather were called Milla İsmail and Milla Yusuf respectively, which, in turn, led to the naming of the latter's family and descendants as the Milla Yusuflar, or the Milla Yusufs. Ali Dede is certain that it was his greatgrandfather Milla Yusuf who trained Hasan Efendi and that he was mentioned in the colophon in return. ${ }^{77}$

Given Hasan Efendi's young age when copying the texts, this was presumably part of his training - the unsteady and rather muddled handwriting suggests this, too. Ebu Müslim (MS 10) is possibly another example of this practice as it is

76 In MS 4, fol. $107^{\mathrm{r}}$, for instance, its scribe Topal Hasan used the colophon to mention his lineage, but most of the colophon was erased (on purpose). And the scribe Hasan Efendi emphasised his descent from Teslim Abdal in the colophon of MS 2, fol. $58^{\mathrm{r}}$.

77 Interview with Ali Göktürk Dede by Janina Karolewski, 3 Oct. 2013, Malatya, Turkey. 
also written in unsteady handwriting, parts of which are even illegible. Since the last few pages of this manuscript are missing and may have contained a date, we can only speculate about the scribe, Yusuf Efendi, son of İsmail, who says in the colophon that his father educated him. Following Ali Dede's claim that his father Yusuf Çavuş (1899/1900-1989) was the scribe of Ebu Müslim, ${ }^{78}$ he must have done the copying before he was fifteen or sixteen years old. This would support my hypothesis that the scribe was in his early years of training.

Once again, it is Hatice Hatun that contains evidence of teaching activities in Şeyh Hasan Köyü. Marginalia in the book reveal that it passed into the hands of Hüseyin Efendi, the nephew of its scribe, Hasan Efendi, and Ali Dede's teacher later. A short annotation that was probably written by Hoca Mehmed Efendi (b. May/June 1858) ${ }^{79}$ is particularly interesting (see Fig. 4): 'In 1321, Hacı Ağa's grandchild Hüseyin Efendi went to Yusuf Ağa’s son Mehmed Efendi for tuition. He acquired knowledge and left in 1323, ${ }^{80}$ Hüseyin Efendi may not have received any training from his uncle Hasan Efendi, whose book - Hatice Hatun - he used and owned, but he did study with Hoca Mehmed Efendi, namely from $1321 \mathrm{AH}$ (1903/1904) to 1323 AH (1905/1906). Just as Ali Dede stayed at the Fountain of Hac1 Ağa outside the village because his teacher lived there, young Hüseyin Efendi must have been obliged to lodge with his teacher Hoca Mehmed Efendi in the village. Like Ali Dede and Hasan Efendi, Hüseyin Efendi was around thirteen years old when his training started. The students that Hoca Mehmed Efendi taught and about whom Ali Dede reports included his own son, Hasan Gültekin (1895-1941/1942), aka Topal Hasan. Topal Hasan later settled in Hilan Köyü (now known as Uğrak, part of Dilek Mahallesi), which lies approximately 40 kilometres west of Şeyh Hasan Köyü on the other side of the Euphrates, where he worked as a teacher (hoca) and looked after his family's religious followers who lived there. ${ }^{81}$

I assume that Hoca Mehmed Efendi used Hatice Hatun when he taught Hüseyin Efendi. The book may have been in his possession or Hüseyin Efendi may have brought it along with him. It is also very likely that he used Müseyyib Gazi for his lessons since its marginalia suggest that the book had been in the

78 Interview with Ali Göktürk Dede by Janina Karolewski, 8 Oct. 2013, Malatya, Turkey.

79 This date is based on two notes on his birth in Şevval 1274 AH (May/June 1858) in Müseyyib Gazi, probably written by his father Yusuf Ağa (MS 1, fols $162^{\mathrm{v}}$ and $233^{\mathrm{r}}$ ).

80 'Ḥacı Ag̉a'nıñ ḥafīdi Ḥüseyin Efendī sene 321 tārīhninde Yūsuf Ag̉a'nıñ maḩdūmı Meḥmed Efendī yanına oḳuma geldi için 'ilm peydā èdüb sene 323 tārīhinde çılḳdı' (MS 2, fol. 23²). I thank my colleague Hülya Çelik, Ruhr-Universität Bochum, for her well-reasoned comments on my reading of this and the following quote (footnote 82).

81 Interview with Ali Göktürk Dede by Janina Karolewski, 2 Oct. 2018, Malatya, Turkey. 
family of Hoca Mehmed Efendi for quite a while. This is particularly surprising because the manuscript was a religious endowment (vakff) to the tekke of Şeyh Ahmed Dede. If we rule out the possibility that someone went to the tekke every now and then to read the text and make private notes in the book, then Müseyyib Gazi must have been in the hands of Hoca Mehmed Efendi's father Yusuf Ağa by 1858 at the latest (see n. 79), only a few decades after it was donated in 1820. Perhaps, it was common practice in the village for the ocak members, who were responsible for the tekke anyway, to take endowed books with them, keep them in their household and write notes in them. Ultimately, they did not seriously violate the vakuf conditions stated in the colophon (see Fig. 5). ${ }^{82}$

Although the manuscript did not stay at the tekke as one would expect, it did remain in the village. And several people read and listened to the epic of Müseyyeb b. Necebe, complying with the request in the colophon. The book will have been removed from the tekke in 1925 at the latest when its closure was decreed by law. But as Ali Dede stressed, he did not see the tekke of Şeyh Ahmed Dede, which was said to have collapsed..$^{83}$ This could be another reason for the removal of Müseyyib Gazi from its place of donation.

Ownership statements and other private notes are tracks which show who had access to the books and used them. One illustrative case is that of Ali Dede's teacher Hüseyin Efendi, who was probably one of the last educational 'hubs' in the village. It is not surprising that the photograph of him one can find on the internet and in houses of relatives, for example, depicts him sitting with a book in his hands. ${ }^{84} \mathrm{He}$ is said to have been a passionate reader with a command of calligraphy, writing it in a clear hand. The manuscripts that relate to him bear witness to this skill. Nonetheless, Hüseyin Efendi does not differ in any great respect from other users and owners of the manuscripts, as he hardly annotated the texts they contained. The only exception worth mentioning here concerns a copy of 'Divan-i Nizamoğlu' by Topal Hasan (MS 4), in which he left several short comments and made corrections on religious beliefs that he did not feel were adequately reflected in the poems. Additionally, he noted the date of Topal

82 'You should not let [the book] be put in another place or desire it. It should only be read and listened to in Şeyh Hasan [Köyü]. Anyone who takes [the book] to village so-and-so and thinks 'I can own [it] myself' will be far away from the intercession of the victorious fighters and martyrs of this book and from God's mercy.' ('[...] sā’ir yere çlḳartmaya heves etmeyesiniz hemān Şeyh Ḥasan'da oḳunub diñlene filān köye götürüb șāhịib olurum diyen bu kitābıñ içindeki gaāzīleriñ ve şehīdleriñ şefā 'atinden ve ḥaḳḳ̂ñ raḥmetinden dūr ola.') (MS 1, fol. $232^{r}$ ).

83 Interview with Ali Göktürk Dede by Janina Karolewski, 2 Oct. 2018, Malatya, Turkey.

84 See Aydın, Topalcengiz and Onarlı (s.a.). 
Hasan's death twice, emphasising that he had been the scribe of this book (MS 4, fol. 29v and 69v) (see Fig. 6).

Hüseyin Efendi usually left ownership statements or private notes which enable us to name some of his readings with certainty. Hatice Hatun, the book that he had received from his uncle Hasan Efendi, must have been particularly dear to him since he continued to use it for family-related notes just like his uncle had done. It is a fine example of how families kept such records and added extra value to the volumes by doing so. In Ebu Müslim, Hüseyin Efendi only seems to have left an ownership note, but it is a well-phrased one that is impressive, filling the margin in a calligraphic manner. It reads: 'The owner of this book is your servant Hüseyin, son of İbrahim, son of Hacı Ağa. O Lord, forgive our sins, drown them in the ocean of mercy'. ${ }^{85}$ He added his title, 'efendi', in tiny writing a little way from his name, as if he was trying to accommodate both his humbleness towards God and his higher social status in the statement.

Ebu Müslim further exemplifies how manuscripts that changed owners for educational purposes, such as teaching a class of pupils or self-study, became keepsakes that were not read any longer. The earliest marginal note in it that I found is from 1330 maliye (1914/1915) and it says that a man from Atabey Köyü, an Alevi village that lies on the opposite side of the Euphrates further downstream, has been killed in battle (probably World War I) and that his son was born the very same year. Given that Ali Dede claims that the manuscript was copied by his father, Yusuf Çavuş, this note could have been written by him. A subsequent entry is from Ali Dede, who used Arabic and Latin characters to record the beginning of the military service that his brothers İsmail (b. 1927) and Hüseyin (b. 1929) had to do in 1944 and 1947 respectively. Another entry by him from 1951 suggests that Hüseyin Efendi received the book that year or later, as Ali Dede remembers Hüseyin Efendi asked for it in order to study the text. ${ }^{86}$ Still, it seems that Ebu Müslim did not remain in his hands for very long, as Veysel Dede's brother Hüseyin Gültekin (b. 1928) made several notes in Latin characters in its margins in 1955. Interestingly, he also added a note on the scribe who copied the book, which reads: 'Dear brothers, Milla İsmail is said to have copied this book' ${ }^{87}$ His careful wording may indicate that his skills in Ottoman Turkish were not good enough for him to decipher the scribe's name in the colophon; either he misinterpreted the name formula 'Yusuf, son of İsmail' or he relied on hearsay when he

85 'Bu kitābıñ șāhịibi Ḥacı Ag̉a’nıñ og̉lı İbrāhīm og̣lı Ḥüseyin bendeleridür bağışla șucımızı yā rabb ki raḥmet baḥrine ġark èt.' (MS 10, fol. 120v).

86 Interview with Ali Göktürk Dede by Janina Karolewski, 2 Oct. 2018, Malatya, Turkey.

87 In Turkish, 'Sayın kardeşler bu kitabı mıla ismayel yazmış.' (MS 10). 
wrote this note. Probably, neither Hüseyin Gültekin nor his brother Veysel Dede were able to use the manuscript for their education the way Milla Yusuf, Ali Dede and Hüseyin Efendi had done before them.

\section{Final remarks}

While it is still unclear to what extent external schooling facilities were used, my research shows that the family networks in Şeyh Hasan Köyü possessed a selfsufficient educational system of their own in the nineteenth and early twentieth century. As we have seen, the manuscripts from Şeyh Hasan Köyü were circulated in the village community in order to hand down textual knowledge among the male members of the ocak. The copying of texts by inhabitants of Şeyh Hasan Köyü gives us clues about the presence of other books that were used as exemplars: These manuscripts may have been kept in the village, borrowed from elsewhere or consulted in other places.

Most of the manuscripts from the village are widely dispersed now, being in the hands of several families living in different parts of Turkey or abroad. It was not possible to trace all these private collections and gain access to the manuscripts. Hopefully, future research on Şeyh Hasan Köyü and its manuscript culture will be able to add more detail and colour to the modest picture I have drawn of it here. In view of this situation, no conclusions can be drawn on textual 'completeness' based on the range of manuscripts of which I am aware. If anything, one could speculate on why certain family members have specific manuscripts in their possession (or why they do not).

Most of the manuscripts examined for this article were collective rather than personal belongings. Up until recently, they were not kept by the scribes and their direct descendants as a keepsake, but changed owners frequently. Dedes who were involved in educational activities presumably served as temporary 'hubs' where books were collected for teaching purposes and self-study before being passed on to another dede who acted as a teacher or sought further readings in order to improve or refresh his own knowledge, for example.

The line of teachers I have reconstructed shows that teaching was not always done by a father instructing his own son, but some teachers and pupils were certainly relatives, either close ones or distant. Ali Dede, for instance, did not have the chance to get any training from members of his own family and therefore joined an educational network of families that all claim descent from Şeyh Şemseddin, a grandchild of Şeyh Ahmed Dede. The books that Ali Dede used during his training and received later from his teacher Hüseyin Efendi bear witness 
to individuals with this lineage. Even Müseyyib Gazi and Ebu Müslim, the two manuscripts probably written by scribes from Ali Dede's family, were in the hands of the Şeyh Şemseddin lineage. While the former found its way into Ali Dede's collection, the latter is now in the hands of Veysel Dede, who has a Şeyh Şemseddin lineage.

The fact that most of the manuscripts available to us from Şeyh Hasan Köyü were copied in the nineteenth century is not surprising, as it is actually common to such collections in general. Presumably, this is not only due to the higher probability of accessing recent written sources as compared to older ones, but it hints at 'heydays' of manuscript culture in some Alevi villages in the late Ottoman Empire and early Republican Era, a period of social reform and transformation. But education in reading and writing Ottoman Turkish came to an end in most Alevi village communities around the late 1950s, a few decades after the alphabet reform in 1928. Like many others from Şeyh Hasan Köyü, Ali Dede moved to Malatya once he had started working in the city's state-run sugar factory in the mid-1950s. His sons neither learnt Ottoman Turkish from him, nor did they receive any specific religious training from him. Nonetheless, his son Selahattin Göktürk, who now lives in Germany, is the chairman of the Alevi Cultural Centre of Cologne ('Alevi Kültür Merkezi Köln'), thus representing what Markus Dressler has called 'the modern dede, ${ }^{88}$ who no longer receives the same training as his father and grandfather. ${ }^{89}$

\section{List of manuscripts}

MS 1 (= Müseyyib Gazi). Manuscript book; paper; 233 folia; Turkish in Arabic script; single work; title: ‘Kitab-i Sultan Müseyyeb Gazi’; scribe: Kılıçoğlu Mılla İsmail ibn Seyyid Yusuf ibn Kul Mustafa; date: 10 Cemazi I 1235 AH (25 February 1820); place: not mentioned, but probably Şeyh Hasan Köyü; ${ }^{90}$ size: $15 \times 21 \times 4.5 \mathrm{~cm}$; present collection: privately owned by Ali Göktürk Dede, Malatya, Turkey. See Fig. 5.

88 Dressler 2006.

89 I am profoundly grateful to Benjamin Weineck, Universität Bayreuth, for his early interest in and much needed support of this contribution. I also wish to thank him for reading and commenting on an earlier version of this contribution.

90 I cannot be sure that all the scribes whom I believe were inhabitants of Şeyh Hasan Köyü copied texts for their manuscripts in the village. This is very likely, but I also know about visits to other villages where they could equally have copied texts for their own ends. This applies to all the manuscripts in the list that are presumed to have been copied in Şeyh Hasan Köyü. 
MS 2 (= Hatice Hatun). Manuscript book; paper; 70 folia; Turkish in Arabic script; six texts, among others: 'Hikayet-i Hadice Hatun' (fols $1^{\mathrm{v}}-24^{\prime}$ ), 'Hikayet-i Mansur' (fols $41^{\text {r }}$ 52'), 'Hikayet-i Cümcüme' (fols 53'-57'), 'Kitab-i ibrahim Edhem' (fols 59'-69v); scribe: Seyyid Hasan Efendi bin Seyyid el-Hacı Mustafa Ağa bin Seyyid Hasan Askeri bin Seyyid Derviş Muhammed; date: 8 Şaban 1268 AH (28 May 1852 CE) and Muharrem 1270 AH (October/November $1853 \mathrm{CE}$ ); place: not mentioned, but probably Şeyh Hasan Köyü; size: $16 \times 21.5 \times 1.5 \mathrm{~cm}$; present collection: privately owned by Ali Göktürk Dede, Malatya, Turkey. See Fig. 4.

MS 3 (= Hüsniye). Manuscript book; paper; 108 folia, last folia missing; Turkish in Arabic script; single work; title: ‘Kitab-i Hüsniye'; scribe: not mentioned, but presumably Topal Hasan (see MS 4); date: not mentioned, but a marginal note gives the terminus ante quem as 1955 and my assumption about the scribe (see above) suggests 1897-1943; place: not mentioned, but presumably Şeyh Hasan Köyü; size: $11.5 \times 17.5 \times 1.5 \mathrm{~cm}$; present collection: privately owned by Ali Göktürk Dede, Malatya, Turkey.

MS 4 Manuscript book; paper; first folio missing, 107 folia in all; Turkish in Arabic characters; single work; title: not mentioned, presumably 'Divan-i Nizamoğlu’ by Seyyid Nizamoğlu (d. 1601); scribe: Topal Hasan Efendi; date: 9 Ramazan 1333 AH or 9 Temmuz 1331 maliye (22 July 1915 CE); place: not mentioned, presumably Şeyh Hasan Köyü; size: $17 \times 24 \times 1 \mathrm{~cm}$; present collection: privately owned by Ali Göktürk Dede, Malatya, Turkey. See Fig. 6.

MS 5 Manuscript booklet, cönk type; paper; 94 folia; Turkish in Arabic characters; collection of poems by Teslim Abdal, Pir Sultan Abdal, Şah Hatayi and many others; scribe: not mentioned; date: not mentioned, but presumably around $1270 \mathrm{AH}(1853 \mathrm{CE})$; place: not mentioned; size: $7.6 \times 19.6 \times 0.6 \mathrm{~cm}$; present collection: privately owned by Ali Göktürk Dede, Malatya, Turkey.

MS 6 Manuscript book; paper; first and last folia missing, number of folia unknown; Arabic; Qur'an copy; scribe, date and place: not mentioned; size: $14.5 \times 21.5 \times 2 \mathrm{~cm}$; present collection: privately owned by Ali Göktürk Dede, Malatya, Turkey.

MS 7 Manuscript book; paper; first and last folia missing, number of folia unknown; Arabic; Qur'an copy; scribe, date and place: not mentioned; size: $14.4 \times 21.5 \times 2 \mathrm{~cm}$; present collection: privately owned by Aydın Gültekin Dede, Malatya, Turkey.

MS 8 Manuscript book; paper; commercially available blank book with squared pages; 111 folia; Turkish in Arabic script; single work; no title, but presumably 'Kitab-i Kerbela' by Darendeli Bekayi (d. 1785) (similar to MS 9); scribe: Kangallı Topal Ahmed; date: 14 Mart 1363 maliye (27 March 1947); place: not mentioned; size: $19 \times 27 \times 2 \mathrm{~cm}$; present collection: privately owned by Ali Göktürk Dede, Malatya, Turkey. 
MS 9 Manuscript book; paper; first folio missing, 124 folia; Turkish in Arabic script; single work; no title, but presumably 'Kitab-i Kerbela' by Darendeli Bekayi (d. 1785) (similar to MS 8); scribe: es-Seyyid Muhammed Bedri bin müezzin Ali Efendi el-mulakkab bi-Leblebicizade; date: Rebi II 1288 AH (June/July 1871 CE); place: not mentioned; size: $17 \times 24 \times 2.5 \mathrm{~cm}$; present collection: privately owned by Ali Göktürk Dede, Malatya, Turkey.

MS 10 (=Ebu Müslim). Manuscript book; paper; first folia missing, approx. 165 folia; Turkish in Arabic script; single work; no title, but presumably 'Kitab-i Ebu Müslim'; scribe: İsmail oğlu Yusuf Efendi; date: not mentioned, but a marginal note gives the terminus ante quem as 5 Kanun I 1330 maliye (18 December 1914); place: karye-i Şeyh Hasan; size: $22.5 \times 32 \times 7 \mathrm{~cm}$; present collection: privately owned by Veysel Gültekin Dede, Malatya, Turkey.

MS 11 (=Ahmed Zemci). Manuscript book; paper; first folia missing, approx. 86 folia; Turkish in Arabic script; single work; no title, presumably 'Kitab-i Ahmed Zemci'; scribe: not mentioned; date: not mentioned, but a marginal note gives the terminus ante quem as $1180 \mathrm{AH}(1766 / 67 \mathrm{CE})$; place: not mentioned; size: $15 \times 21 \times 2.5 \mathrm{~cm}$; present collection: privately owned by Veysel Gültekin Dede, Malatya, Turkey.

MS 12 Manuscript document; scroll; paper; Arabic; presumably a genealogical certificate (şecere) for a member of the Şeyh Ahmed Dede Ocağı; scribe: not mentioned; date: 1135 AH (1722/23 CE); place: Kerbela; size: not measured; present collection: privately owned by Ali Göktürk Dede, Malatya, Turkey.

\section{References}

‘1987 Öncesi’ (s.a.), ‘1987 Öncesi Şeyh Hasan Köyü’, on Şeyh Ahmed Dede Ocağı Resmi Web Sayfası (ed.), <https://www.seyhahmeddedeocagi.com/foto\%C4\%9Fraflar/1987-\%C3\% B6ncesi-\%C5\%9Feyh-hasan-k\%C3\%B6y\%C3\%BC/> (accessed on 20 Dec. 2020).

Akın, Bülent and Ozan Yılmaz (2017), 'Şeyh Ahmed Dede Ocağı’nın Yeniden Zuhuru: Teslim Abdal Ocağı (Yazılı Kaynaklar)', in Alevilik-Bektaşilik Araştırmaları Dergisi, 16: 71-138. Aksüt, Ali (2013), 'Kabileler: Şeyh Hasanlılar’, on Fethiye’nin Dünyaya Açılan Penceresi (ed.), <http://www.aliseydi-sevim.com/haber_detay.asp?haberID=167> (accessed on $20 \mathrm{Dec}$. 2020).

Albayrak, Nurettin (1994), 'Ebû Müslim Destanı', in Türkiye Diyanet Vakfı (= TDV) (ed.), TDV İslâm Ansiklopedisi, vol. 10, Dûmetülcendel-Elbise, Istanbul: TDV İslâm Araştırmalar Merkezi, 195-196.

Andrews, Peter and Hıdır Temel (2010), 'Hubyar', British Journal of Middle Eastern Studies, 37/3: 287-334.

Aşan, Muhammed Beşir (1987), ‘Tabanbükü (Şeyh Hasan) Köyü Mezarlıkları’, in Fırat Havzası Araştırma Merkezi (ed.), Fırat Havzası Yazma Eserler Sempozyumu, 5-6 Mayıs 1986, Elazığ, Bildiriler, Elazığ: Fırat Üniversitesi, 147-169. 
Aşan, Muhammed Beşir (1998), 'Fırat Kenarında bir Horasan Ereni Şeyh Ahmed Dede', in I. Uluslararası Türk Dünyası Eren ve Evliyaları Kongresi Bildirileri, 13-16 Ağustos 1998, Ankara, Ankara: Ervak, 53-62.

Aşan, Muhammed Beşir (2005), 'Fırat Havzasında Tespit Edilen Vefâi Silsile-Nâmesi ve Bazı Düşünceler', in XIV. Türk Tarih Kongresi, 09-13 Eylül 2002, Ankara, II. Cilt, II. Kısım (Türk Tarih Kurumu Yayınları IX, 14b), Ankara: Türk Tarih Kurumu, 1517-1524 [+ 1 figure and 16 plates].

Aydın, Ayhan, Kalender Topalcengiz and İsmail Onarlı (s.a.), 'Hüseyin (Efendi) Karaduman Dede ve Ahmet Yesevi Üzerine ...', on Şeyh Ahmed Dede Ocağı Resmi Web Sayfası (ed.), <https://www.seyhahmeddedeocagi.com/alevilik/h\%C3\%BCseyin-efendi-karadumandede/> (accessed on 20 Dec. 2020).

Babayan, Kathryn (2002), Mystics, Monarchs and Messiahs: Cultural Landscape of Early Modern Iran (Harvard Middle Eastern Monographs, 35), Cambridge, MA: Harvard University Press.

De Rosa, Sinibaldo (2019), 'Theatre Adaptation, Ritual Movements and Alevi Frontiers', in Hanna Walsdorf and Kathrin Stocker (eds), Ritual Tanz Bühne (Prospektiven: Workshopberichte der Emmy Noether-Nachwuchsgruppe ‘Ritualdesign für die Balletbühne’, 3), Leipzig: Leipziger Universitätsverlag, 43-66.

Dressler, Markus (2002), Die alevitische Religion: Traditionslinien und Neubestimmungen (Abhandlungen zur Kunde des Morgenlandes, 53/4), Würzburg: Ergon Verlag.

Dressler, Markus (2006), 'The Modern Dede: Changing Parameters for Religious Authorities in Contemporary Turkish Alevism', in Gudrun Krämer and Sabine Schmidtke (eds), Speaking for Islam: Religious Authorities in Muslim Societies (Social, Economic, and Political Studies of the Middle East and Asia, 100), Leiden: Brill, 269-294.

Dressler, Markus (2008), 'Alevīs', in Gudrun Krämer, Denis Matringe, John Nawas and Everett Rowson (eds), Encyclopaedia of Islam, THREE, vol. 2008-1, Leiden: Brill, 93-121.

Dressler, Markus (2013), Writing Religion: The Making of Turkish Alevi Islam (Reflection and Theory in the Study of Religion), Oxford: Oxford University Press.

Eren, Hulusi (2014), Dârendeli Kâtipzâde Bekâyî - Maktel-i Hüseyn (İnceleme - Tenkitli Metin Sözlük Dizin), unpubl. MA thesis, Hacettepe Üniversitesi, Ankara. [Available online on Yükseköğretim Kurulu Başkanlığı Ulusal Tez Merkezi <https://tez.yok.gov.tr/ UlusalTezMerkezi/TezGoster?key=1zw6GvYMe-q3Hf6HR-3US9aAD0b-02vex-3j2FWvZ_ n0JKAom14n6JEW5pX1rbdp> (accessed on 20 Dec. 2020)].

Ersal, Mehmet (2016a), 'Cönkten Hizmet Defterine, İcradan Yazıya: Alevi Yazma Geleneği', Millî Folklor, 111: 87-99.

Ersal, Mehmet (2016b), Alevilik: Kavramlar ve Ocak Sistemi. Çubuk Havzası Örneği (Gazi Üniversitesi Türk Kültürü ve Hacı Bektaş Veli Araştırma Merkezi Yayınları Araştırma Dizisi, 25), Ankara: Gazi Üniversitesi Türk Kültürü ve Hacı Bektaş Veli Araştırma Merkezi Yayınları.

Ertaş, Kasım (2016), 'Türk Dili ve Ermeniler: Osmanlı'nın Ermeni Dilbilimcileri', The Journal of Academic Social Science Studies, 53: 151-162.

Ertuğ, Füsun (2000), 'An Ethnobotanical Study in Central Anatolia (Turkey)', Economic Botany, 54/2: 155-182.

Faroqhi, Suraiya (1995), Kultur und Alltag im Osmanischen Reich: Vom Mittelalter bis zum Anfang des 20. Jahrhunderts, Munich: C. H. Beck.

Fölster, Max Jakob, Janina Karolewski et al. (2015), 'Questionnaire for the Study of Manuscript Collections (Towards a Typology of Manuscript Collections)' (CSMC - Occasional Papers, 4), <http://www.manuscript-cultures.uni-hamburg.de/papers_e.html> (accessed on 20 Dec. 2020). 
Georgeon, François (1995), 'Lire et écrire à la fin de l'Empire ottoman : Quelques remarques introductives', Revue des mondes musulmans et de la Méditerranée, 75-76:169-179.

Hendrich, Béatrice (2018), 'Location(s) of Memory and Commemoration in Alevi Culture: Incorporation and Storage', in Johannes Zimmermann, Janina Karolewski and Robert Langer (eds), Transmission Processes of Religious Knowledge and Ritual Practice in Alevism between Innovation and Reconstruction (Geschichte und Kultur des modernen Vorderen Orients, Heidelberger Studien / History and Culture of the Modern Near and Middle East, Heidelberg Studies, 39), Berlin: Peter Lang, 37-76.

Kaplan, Doğan (2010), Yazılı Kaynaklarına Göre Alevilik (Türkiye Diyanet Vakfı Yayın 461, İlmi Eserler Serisi, 82), Ankara: Türkiye Diyanet Vakfı.

Karadağ, Recep (2007), Doğal Boyamacılık, Ankara: T. C. Kültür ve Turizm Bakanlığı.

Karakaya-Stump, Ayfer (2010), 'Documents and Buyruk Manuscripts in the Private Archives of Alevi Dede Families: An Overview', British Journal of Middle Eastern Studies, 37/3: 273-286.

Karakaya-Stump, Ayfer (2012/2013), 'The Vefä'iyye, the Bektashiyye and Genealogies of “Heterodox” Islam in Anatolia: Rethinking the Köprülü Paradigm', Turcica, 44: 279-300.

Karolewski, Janina (2015), 'Ritual Text and Music in Turkish Alevism: Dimensions of Transmission and Bearers of Knowledge', in Hendrik Schulze (ed.), Musical Text as Ritual Object, Turnhout: Brepols, 91-110.

Kieser, Hans-Lukas (2005), 'Alevilik als Lied und Liebesgespräch: Der Dorfweise Melûli Baba (1892-1989)', in Robert Langer, Raoul Motika and Michael Ursinus (eds), Migration und Ritualtransfer: Religiöse Praxis der Aleviten, Jesiden und Nusairier zwischen Vorderem Orient und Westeuropa (Heidelberger Studien zur Geschichte und Kultur des modernen Vorderen Orients 33), Frankfurt a. M.: Peter Lang Verlag, 147-161.

Kolaç, Turgay (2018), Konak (Malatya) Yöresi Halk ilaçları, unpubl. MA thesis, İnönü Üniversitesi, Malatya. [Available online on Yükseköğretim Kurulu Başkanlığı Ulusal Tez Merkezi <https://tez.yok.gov.tr/UlusalTezMerkezi/TezGoster?key=Rrl-Krk3ARkF4YfHofukzfCsdOLCj6xrQ-JLQ0t9014NIDBBq3YU6kfZF4KhNiA> (accessed on 20 Dec. 2020)].

Mélikoff, Iréne (1962), Abū Muslim: Le “Porte-Hache” de Khorasan dans la tradition épique turco-iranienne, Paris: Adrien Maisonneuve.

Mihri [= Mihran Apigian] (1303 AH [1885/1886 CE]), ilaveli Güldeste: Muharrerat-i Resmiye ve Gayr-i Resmiye, Istanbul: Mahmud Bey Matbaası.

Onarlı, İsmail (1999), 'Şeyh Hasan Ocağı ve Aşireti', in Hacı Bektaş Veli Araştırma Dergisi, 12: 25-50.

Onarlı, İsmail (2000), 'Şeyh Hasanlı Aşiretleri Konfederasyonu Oyman ve Obalarının Yerleşik Yörelerindeki Söylence ve İnanç Motiflerinin Nesnel ve Tarihsel Temelleri’, in Hacı Bektaş Veli Araştırma Dergisi, 14: 91-144.

Onarlı, İsmail (2001), Şeyh Hasan Aşireti: Anayurt’tan Anadolu'ya, Istanbul: Aydüşü Yayınları. Otter-Beaujean, Anke (1997), 'Schriftliche Überlieferung versus mündliche Tradition: Zum Stellenwert der Buyruk-Handschriften im Alevitum', in K. Kehl-Bodrogi, B. Kellner-Heinkele and Anke Otter-Beaujean (eds), Syncretistic Religious Communities in the Near East: Collected Papers of the International Symposium 'Alevism in Turkey and Comparable Syncretistic Religious Communities in the Near East in the Past and Present', Berlin, 14-17 April 1995 (Studies in the History of Religions: NUMEN Book Series, 76), Leiden: Brill, 213-226.

Özege, Mehmet Seyfettin (1971-1982), Eski Harflerle Basılmış Türkçe Eserler Kataloğu, 5 vols, Istanbul: Fatih Yayınevi Matbaası. 
Özmen, İsmail (1998), Alevi-Bektaşi Şiirleri Antolojisi, vol. 3, 17.-18. Yüyıl (T.C. Kültür Bakanlığı Yayınları 2064, Yayımlar Dairesi Başkanlığı, Sanat - Edebiyat Eserleri Dizisi 162-31), Ankara: T.C. Kültür Bakanlı̆̆ı.

Rey, Terry (2018), 'Pierre Bourdieu and the Study of Religion: Recent Developments, Directions, and Departures', in Thomas Medvetz and Jeffrey J. Sallaz (eds), The Oxford Handbook of Pierre Bourdieu, New York: Oxford University Press, 299-326.

Serdaroğlu, Ümit (1977), Aşağı Fırat Havzasında Araştırmalar 1975 / Surveys in the Lower Euphrates Basin (ODTÜ Aşağı Fırat Projesi Yayınları, 1/1), Ankara: ODTÜ Aşağı Fırat Projesi. Shankland, David (2003), The Alevis in Turkey: The Emergence of a Secular Islamic Tradition (Islamic Studies Series), London/New York: Routledge Curzon.

Sipahi, Ali (2016), 'Suburbanization and Urban Duality in the Harput Area', in Yaşar Tolga Cora, Dzovinar Derderian and Ali Sipahi (eds), The Ottoman East in the Nineteenth Century: Societies, Identities and Politics (Library of Ottoman Studies, 51), London/New York:

I. B. Tauris \& Co. Ltd, 247-267.

Somel, Selçuk Akşin (2001), The Modernization of Public Education in the Ottoman Empire, 1839-1908 (The Ottoman Empire and its Heritage, 22), Leiden: Brill.

Stanley, Tim (2004), 'Page-Setting in Late Ottoman Qur’āns: An Aspect of Standardization', Manuscripta Orientalia, 10/1: 56-63.

'Tâcû'l-Ârifîn' (s.a.), 'Tâcû'l-Ârifîn Seyyîd Ebû'l-Vefâ Şeceresi Şeyh Ahmed Dede Ocağı'nın Bilinen En Eski Şeceresi (Hicrî 829/Milâdî 1427)', on Şeyh Ahmed Dede Ocağı Resmi Web Sayfası (ed.), <https://www.seyhahmeddedeocagi.com/belgeler/seyyid-\%C5\%9Feyhahmed-dede-\%C5\%9Feceresi/> (accessed on 20 Dec. 2020).

Tee, Caroline (2012), Mysticism and Identity Amongst the Alevis in Turkey: A Study of Flexibility and Adaptation in the aşık Poetry of an Eastern Alevi ocak, PhD thesis, University of Bristol.

Türkiye Illler İdaresi Genel Müdürlüğü (ed.) (1968), Köylerimiz: 1 Mart 1968 Gününe Kadar, Ankara: Başbakanlık Basımevi D. S. i.

Türkoğlu, Serkan (2017), ‘Türk Edebiyatında Maktel-i Hüseyinler ve Bekâînnin Kitâb-ı Kerbelâ Mesnevisi’, Atatürk Üniversitesi Türkiyat Araştırmaları Enstitüsü Dergisi, 58: 107-128.

Ünal, Yusuf (2016), 'More Than Mere Polemic: The Adventure of the Risālah-i Husniyah in the Safavid, Ottoman and Indian Lands', unpubl. MA thesis, Boğaziçi Üniversitesi, Istanbul.

Weineck, Benjamin (2020), Zwischen Verfolgung und Eingliederung: Kızılbaş-Aleviten im osmanischen Staat (16.-18. Jahrhundert) (Kultur, Recht und Politik in muslimischen Gesellschaften, 42), Ergon Verlag: Baden-Baden.

Witkam, Jan Just (2002), 'Twenty-Nine Rules for Qur'ān Copying: A Set of Rules for the Lay-out of a Nineteenth-Century Ottoman Qur'ān Manuscript', in Jan Schmidt (ed.), Barbara Flemming Armağanı II = Journal of Turkish Studies / Türklük Bilgisi Araştırmaları, 26/1: 339-348.

Yıldırım, Rıza (2018), Geleneksel Alevilik: Inanç, ibadet, Kurumlar, Toplumsal Yapı, Kolektif Bellek (iletişim Yayınları, 2677; Araştırma-İnceleme Dizisi, 439), Istanbul: İletişim Yayıncılık.

Yılmaz, Hacı (2017), 'Şeyh Hasan Ocağı ve Vefâilikle İrtibatı', Türk Kültürü ve Hacı Bektaş Veli Araştırma Dergisi, 83: 223-240.

Yinanç, Refet and Mesut Elibüyük (1983), Kanunî Devri Malatya Tahrir Defteri (1560) (Gazi Üniversitesi Yayın, 31; Gazi Eğitim Fakültesi Yayın, 1), Ankara: Ankara Üniversitesi Basımevi.

Zeki [= Bedros Garabedian] (1316 AH [1898/1899 CE]), Muhtasar Nevdeste Yahud Münşeat-i Cedide: Kitabet-i Resmiye ve Gayr-i Resmiye, Istanbul: Mahmud Bey Matbaası. 


\section{Diagram: Family and teacher-student relations}

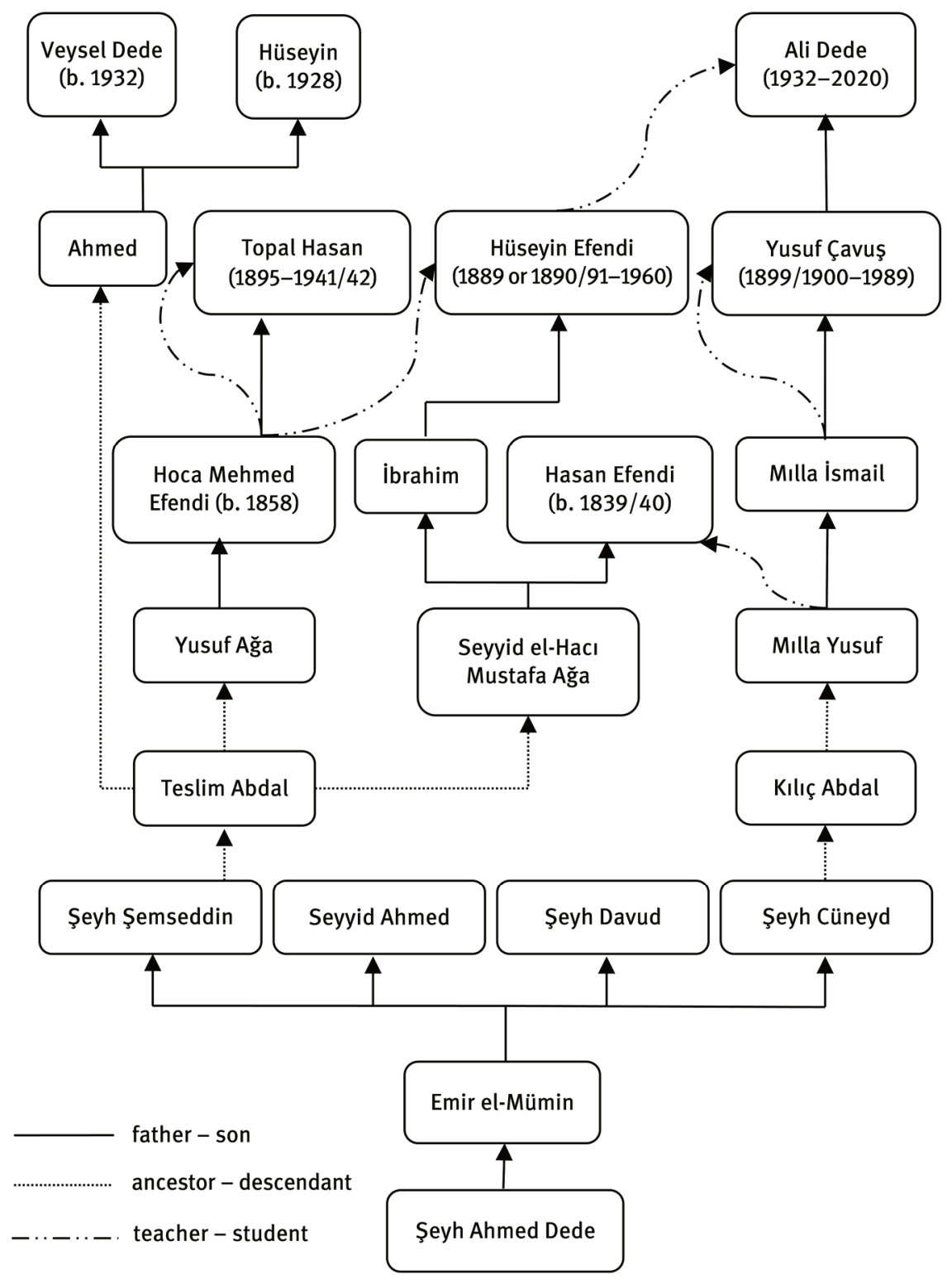




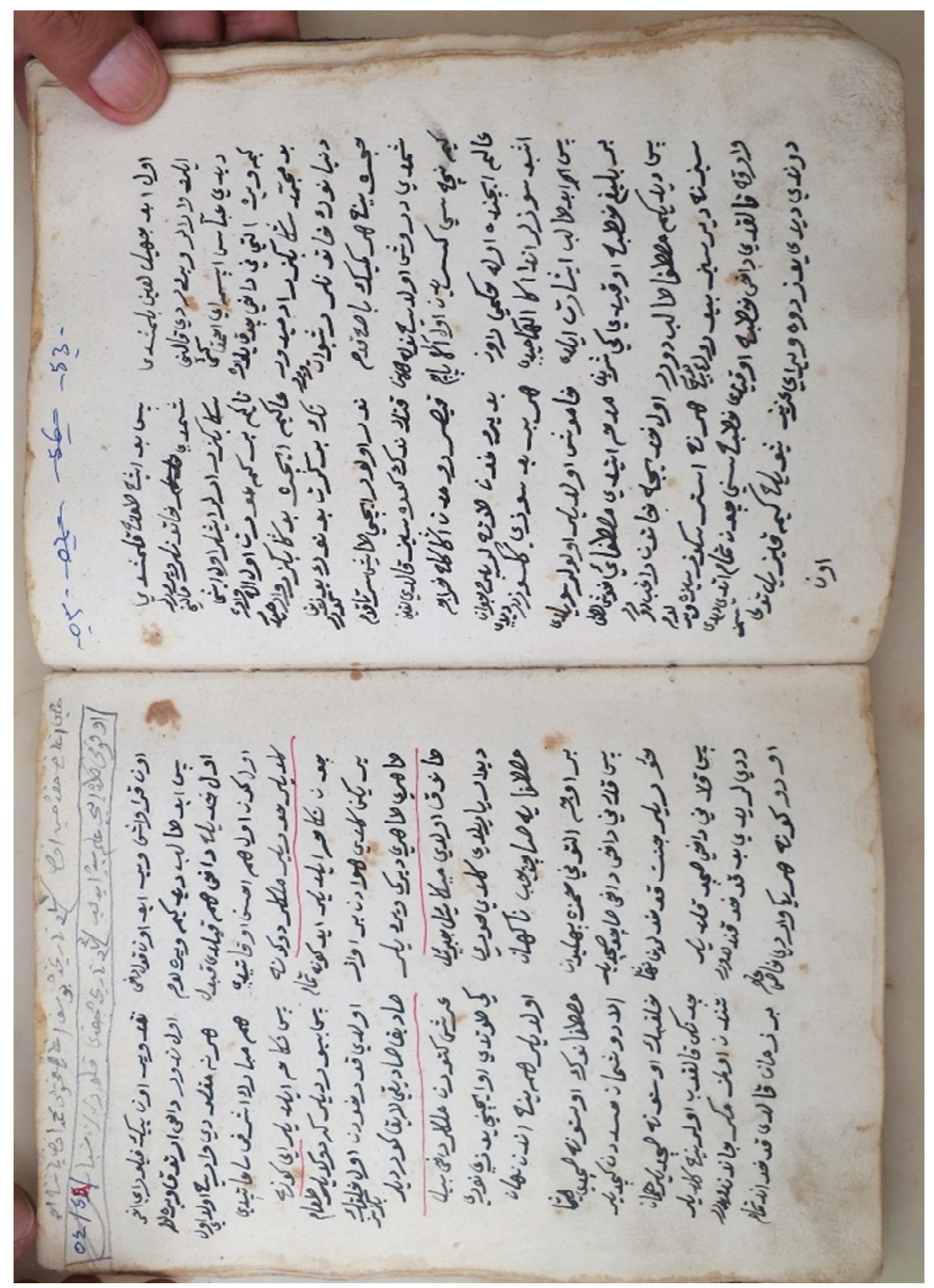

Fig. 4: MS 2, Hatice Hatun, fols $22^{\mathrm{v}}-23^{\mathrm{r}}$, copied by Hasan Efendi on 8 Şaban 1268 AH (28 May 1852) and in Muharrem 1270 AH (October/November 1853 CE). In the upper margin on fol. 23r', there is a note on Hüseyin Efendi's training by Mehmed Efendi from 1321 to 1323 AH (1903/41905/6 CE). (C) Ali Göktürk. Photograph by Janina Karolewski. 


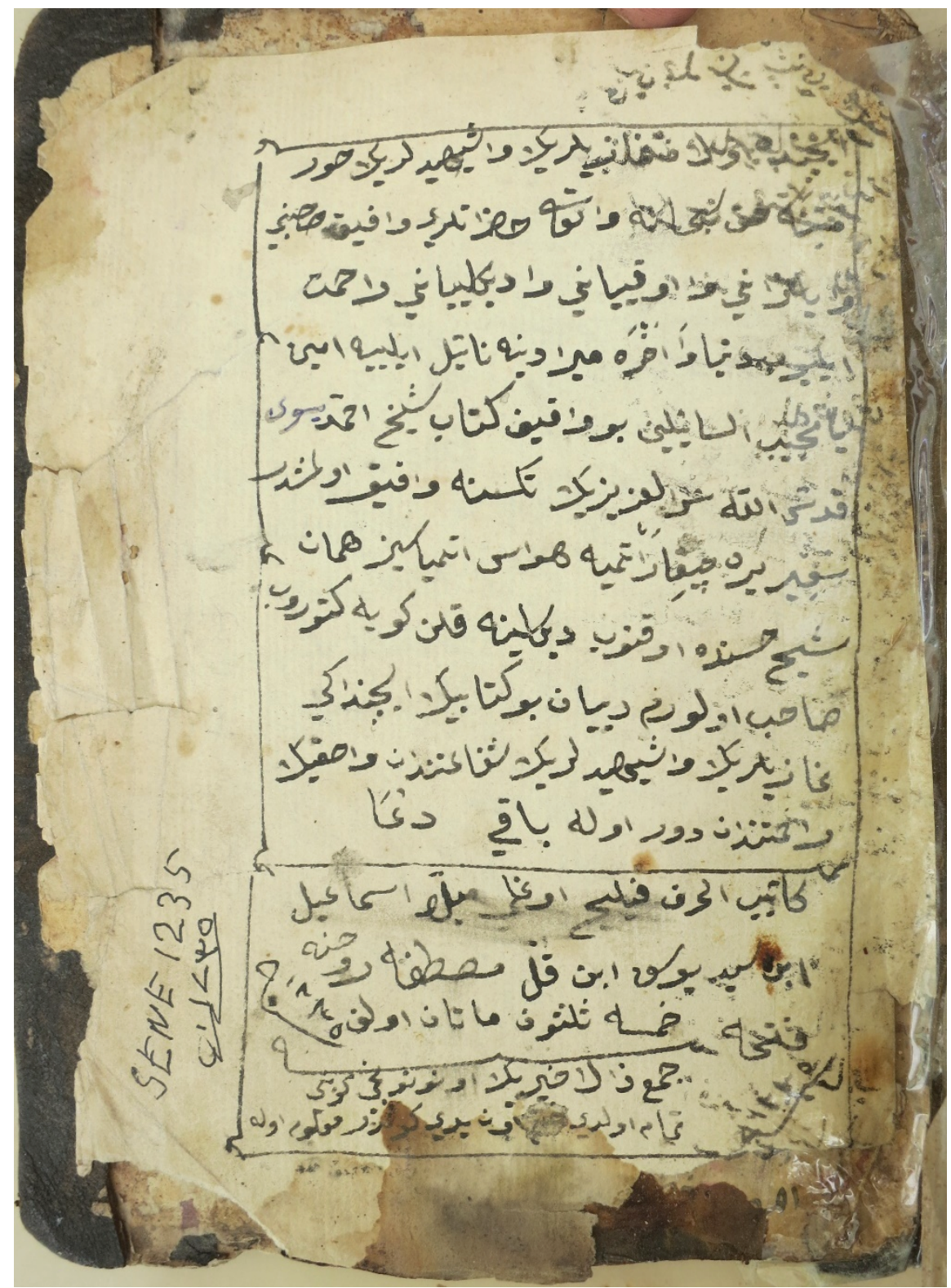

Fig. 5: MS 1, fol. 232' , Müseyyib Gazi, copied by Kılıçoğlu Mılla İsmail on 10 Cemazi I 1235 AH (25 February $1820 \mathrm{CE}$ ). Parts of the book's colophon mention the endowment's conditions, the scribe's name and the date of copying. (C) Ali Göktürk. Photograph by Janina Karolewski. 


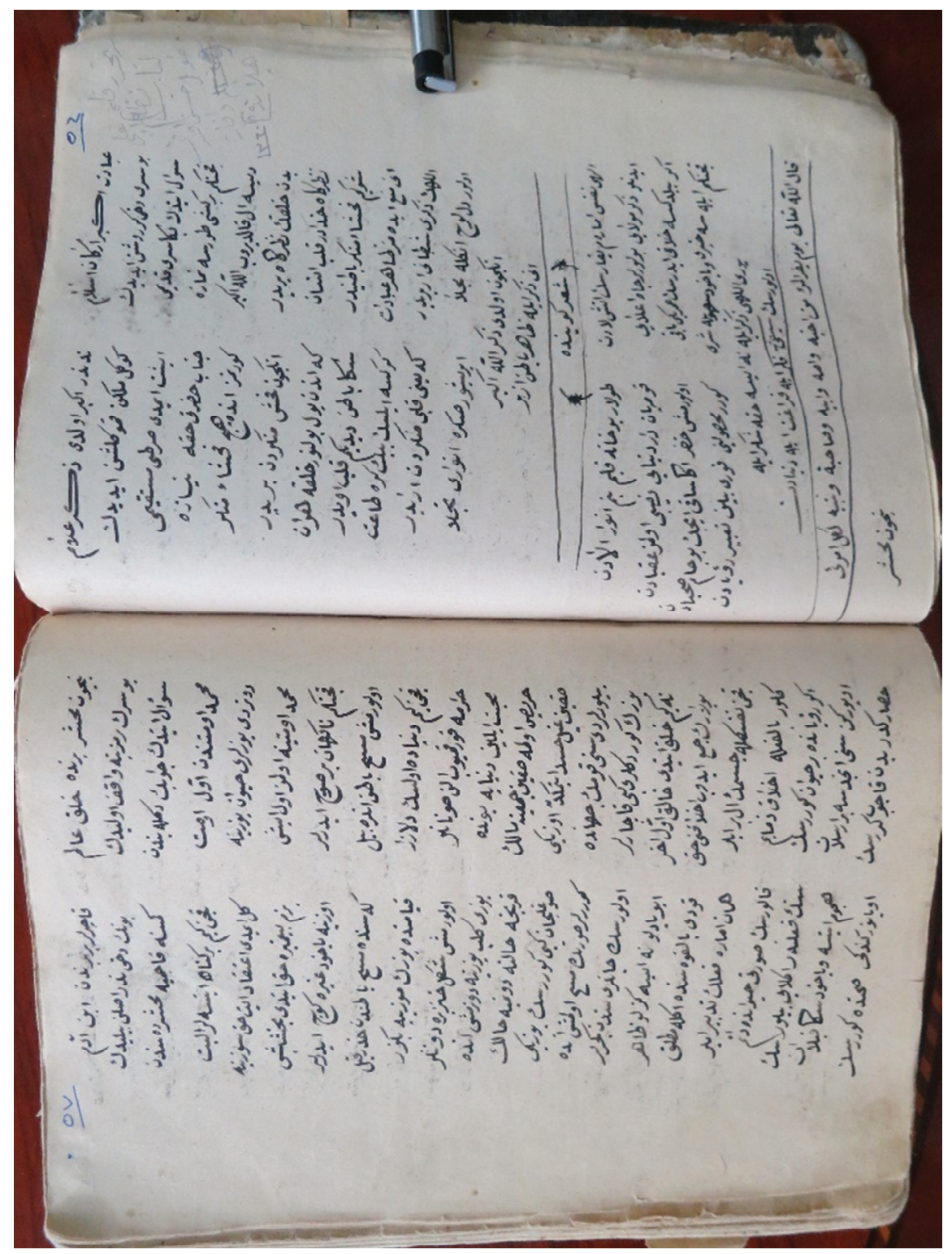

Fig. 6: MS 4, fols $28^{\mathrm{v}}-29^{\mathrm{r}}$ : the poetry collection of Nizamoğlu, copied by Hasan Gültekin, aka Topal Hasan, on 9 Ramazan 1333 AH (22 July 1915 CE). In the upper right-hand margin on fol. $28^{v}$, there is a faint note by Hüseyin Efendi on Hasan Topal's death in 1360 AH (1941/42 CE). (c) Ali Göktürk. Photograph by Janina Karolewski. 